Low-Cost Solar Array Project

5101-84

\title{
MASTER
}

$D O E / J P L--1012-78 / 11$

\section{Bias-Humidity Testing \\ Of Solar-Cell Modules}

\author{
Alan R. Hoffman \\ Emmett L. Miller
}

October 15, 1978

Prepared for

Department of Energy

by

Jet Propulsion Laboratory

California Institute of Technology

Pasadena, California 


\section{DISCLAIMER}

This report was prepared as an account of work sponsored by an agency of the United States Government. Neither the United States Government nor any agency Thereof, nor any of their employees, makes any warranty, express or implied, or assumes any legal liability or responsibility for the accuracy, completeness, or usefulness of any information, apparatus, product, or process disclosed, or represents that its use would not infringe privately owned rights. Reference herein to any specific commercial product, process, or service by trade name, trademark, manufacturer, or otherwise does not necessarily constitute or imply its endorsement, recommendation, or favoring by the United States Government or any agency thereof. The views and opinions of authors expressed herein do not necessarily state or reflect those of the United States Government or any agency thereof. 


\section{DISCLAIMER}

Portions of this document may be illegible in electronic image products. Images are produced from the best available original document. 


\section{$5101-84$ \\ CONTENTS}

I. INTRODUCTION

II. TEST APPARATUS AND TEST SETUP
A. PHASE 1 TESTING
B. PHASE 2 TESTING

III. TEST RESULTS -

A. PHASE 1 TEST RESULTS

1. Visible Changes - 10

2. Electrical Measurements _- 10

B. PHASE 2 TEST RESULTS

1. Visible Changes - 12

2. Electrical Measurements - 14

3. Delamination Test Module

C. CELL EQUIVALENT SHUNT RESISTANCE RESULTS -

D. MODULE INSULATION AND REV̈ERSE BIAS RESISTANCE RESULTS -

IV. CONCLUSIONS - 26

REFERENCES -

APPENDIX

Reverse Bias Voltage Measurement by the Shadowing Technique - A-1

\section{Figures}

1. Types of Modules Subjected to Bias-Humdity Testing - - 3

2. Basic Electrical Schematic for Phase 1 Tests - - - 5

3. Arrangement of Full-Sized Modules in Chamber

for Phase 1 Tests 


\section{$5101-84$}

4. Temperature-Humidity Test Profile

5. Mini-Modules in Environmental Chamber

at Start of Phase 1 Tests

6. Electrical Connections for Phase 2

Ground Plane Effects - 9

7. Electrical Connections for Phase 2

Cell Bias Effects - 9

8. SEM View of Cell No. 38 Showing Various

Forms of Corrosion Products _- 11

9. Dendritic Growth Pattern on Cell No. $38 \ldots \ldots$

10. Example of Tin Migration on Solar Cell After

Bias-Humidity Testing, Phase 2 - 13

11. Scanning Electron Microscope View of Tin

Migration After Bias-Humidity Testing, Phase $2 \ldots \ldots$

12. Cell Shunt Resistance Before and After

Bias-Humidity Testing, Phase 1 - 18

13. Examples of Reverse Bias I-V Curves for

Two Typical Cells -_-_-_ 19

14. Curve Tracer Trace of Reverse Bias Characteristics.

of Four Cells - 20

15. Examples of Reverse Bias I-V Curves for Several

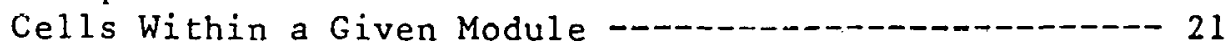

16. Module Insulation Resistance, Phase 1 - 23

17. Module Reverse Bias Resistance, Phase 1 -.........-. 23

18. Mini-Module Reverse Bias Resistance Phase 2 -...-.--- 24

A-1. Four-Point Probe Configuration for

Measurement of Solar Cell Parameters

A-2. Schematic Diagram of Shadow Measurement
Circuitry and Instrumentation

A-3. Composite I-V Curve of One Completely Shadowed

Cell in Series with (N-1) Illuminated Cells $=-\cdots$

A-4. Composite I-V Curve of One Partially Shadowed

Cell in Series with $(\mathrm{N}-1)$ Illuminated Cells $\ldots \ldots$

A-5. Typical Expanded Scale I-V Plot for Reverse

Bias Voltage Determinatiun -.... A-11 


\section{'5101-84}

Tables

1. Design Features of Photovoltaic Modules Tested------ 4

2. Detailed Electrical Connection Information -...-- 5

3. Maximum Power Measurements, Phase 1

4. Summary of Phase 1 Bias-Humidity Test Results -..---- 13

5. Electrical Measurements for Bias-Humidity

Tests, Phase 2 - 15

6. Summary of Phase 2 Bias-Hundity Test Results - 16

7. Comparison of Equivalent Shunt Resistance Results

Obtained by Two Different Methods - 22 


\section{ABSTRACT}

The feasibility of implementing bias-humidity development testing to determine if field-like failure modes would result is demonstrated. Variables resulting in degradation were separated so causative variables could be identified. The studies were done on silicon solar cell modules from different manufacturefrs. Following each of the ten-day bias-humidity tests, the modules were examined, photographed, and tested. Limited bias-related changes were observed. (LEW) 
ABSTRACT

Bias-humidity development testing was conducted in two phases 
Humidity-related degradation of solar cells and modules is well known from both space and terrestrial experience. Current humidity cycling tests being applied to flat plate modules (References 1,2 ) are "survival" tests, i.e., the modules are not operating -- no illumination, no voltage, terminals short-circuited. A standard environmental test in the semiconductor industry is to subject devices to $85^{\circ} \mathrm{C}, 85 \%$ relative humidity while imposing a voltage bias across the device (Reference 3): A TV manufacturer in Japan found a positive correlation between mean time between failures (MTBF) from an accelerated life test (TV set operating) at high temperature and high humidity and MTBF from field conditions (Reference 4). The results indicated that for each hour of operation at $35^{\circ} \mathrm{C}$ and $95 \%$ relative humidity, the manufacturer expected about 16.8 hours of operation under field conditions. Also, experienced people at JPL noted that with an applied voltage-humidity combination using a ground plane the resulting electrolysis would accelerate the deterioration of the insulating material. Furthermore, if a voltage gradient from cell to cell were applied, metal migration may be accelerated. For these reasons, the feasibility and value for solar cell modules of a humidity test combined with a voltage bias was an appropriate subject for research and development.

The objectives of the bias-humidity efforts were:

- Develop testing procedures combining voltage biasing with a humidity cycle for the purpose of accelerating failure mechanisms which may occur in long term field use.

- Define the bias-humidity tolerance of current photovoltaic module designs.

- Define design changes associated with improving bias-humidity tolerance.

- Determine value of bias-humidity testing as a mandatory qualification test.

This report describes the results associated with these efforts. 
Bias-humidity development testing was conducted in two phases. The first phase was to demonstrate feasibility of implementing such a test to determine if field-like failure modes (especially encapsulant delamination) would result. The second phase, a refinement of the first phase, was to separate the variables resulting in Phase 1 degradation so that causative variables could be identified. The Phase 1 studies were conducted on full size Block II modules, one from each manufacturer. The Phase 2 studies utilized three mini-modules from each of four Block II manufacturers. All modules were fabricated with circular silicon solar cells of 50,75 , or $100 \mathrm{~mm}(2,3$, or 4 inches) diameter. Other materials, such as those for cell metallization or module encapsulation, varied widely. Figure 1 shows the eight module types tested. A physical description of the modules is provided in Table 1.

\section{A. PHASE 1 TESTING}

For the Phase 1 testing, two electrical conditions were imposed on the modules during the humidity exposure. One condition consisted of providing a voltage gradient from cell to cell with the current opposite that normally experienced in the field (i.e., reverse biasing). The reason for this condition was to provide a mechanism that may accelerate metal migration, a degradation mode detected by this type of testing in the semiconductor industry. The second condition consisted of placing a ground plane in close proximity to one-half of the front surface of the module. The rationale for the ground plane was to provide a mechanism for stressing the encapsulant to accelerate possible degradation, especially dielectric changes, e.g. deterioration of the insulating characteristics. Also, ground plane "stressing" conditions can conceivably occur in the field when moisture or dust form a conductive film on the module surface. The ground planes for the modules were fabricated from perforated aluminum plates. The ground plane for modules from manufacturers $P$ and $T$ was positioned on the front side so that the half of the cells near the negative terminal was covered. The other half was not covered. The ground $\mathrm{plane}$ for the module from manufacturer $L$ was similarly positioned except that the ground plane was located on the reverse side of the cells. If the module had a conductive frame, the ground plane was electrically connected to the frame.

The basic electrical schematics for the test are shown in Figure 2. A summary of pertinent electrical connection information by module is given in Table 2 .

Overall module power performance was determined by using the pulsed solar simulator before and after the environmental exposure to obtain current-voltage characteristics. Visual inspection reports and photographs were used to document physical changes. 


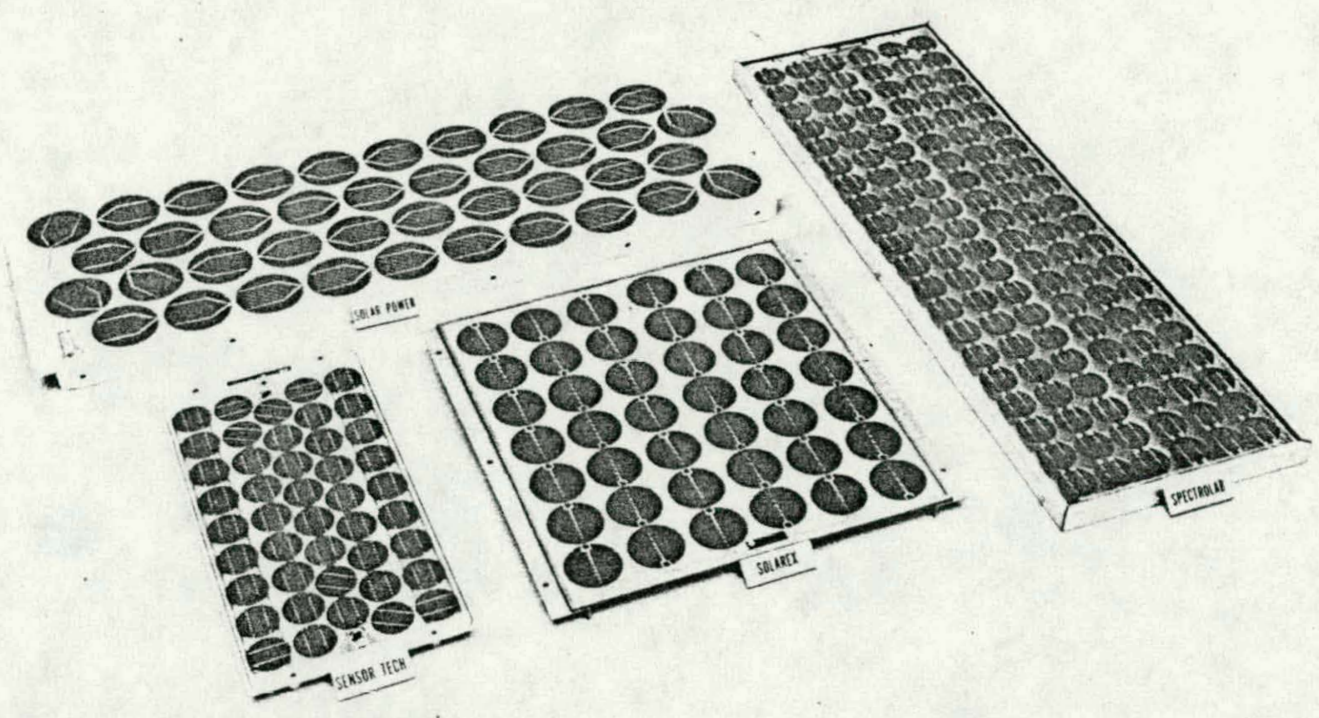

Block II Ful1 Size Modules

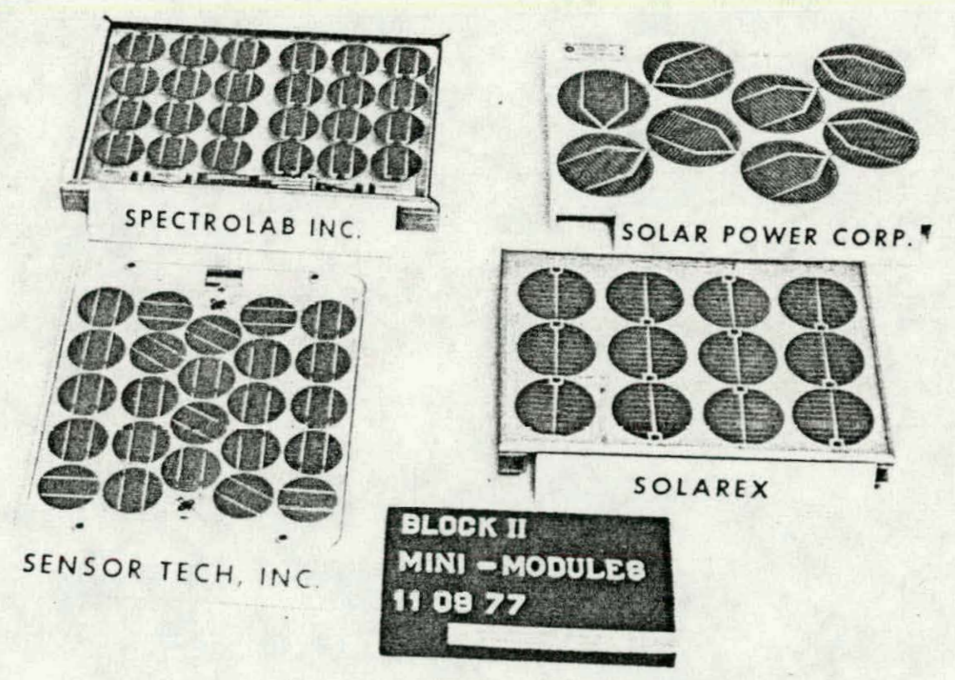

Block II Mini-Modules

Figure 1. Types of Modules Subjected to Bias-Humidity Testing 
Table 1. Design Features of Photovoltaic Modules Tested

\begin{tabular}{|c|c|c|c|c|}
\hline Feature & \multicolumn{4}{|c|}{ MANUFACTURER } \\
\hline Overall Dimensions & $\mathrm{T}$ & $\mathrm{x}$ & $\mathrm{p}$ & L \\
\hline $\begin{array}{l}\text { Full Size (Block II) } \\
\text { Mini-Modules (Block II) }\end{array}$ & $\begin{array}{l}589 \times 290 \times 25 \mathrm{~mm} \\
356 \times 290 \times 25 \mathrm{~mm}\end{array}$ & $\begin{array}{l}582 \times 582 \times 47 \mathrm{~mm} \\
356 \times 268 \times 47 \mathrm{~mm}\end{array}$ & $\begin{array}{r}1168 \times 387 \times 50 \mathrm{~mm} \\
387 \times 280 \times 50 \mathrm{~mm}\end{array}$ & $\begin{array}{r}1168 \times 387 \times 37 \mathrm{~mm} \\
387 \times 285 \times 37 \mathrm{~mm}\end{array}$ \\
\hline $\begin{array}{l}\text { Materials and cell types } \\
\frac{\text { (1n sequence, top to }}{\text { bottom })}\end{array}$ & & & & \\
\hline Top, exposed surface & RTV 615 & Sylgard 184 & $\begin{array}{l}\text { Dow Corning } \\
\text { X1-2577 }\end{array}$ & 2.03 dm float glass \\
\hline Top; encapeulant & RTV 015 & Sylgard 184 & $\begin{array}{l}\text { Sy 1gard } 184 \text { or } \\
\text { RTV 615 }\end{array}$ & Polyvinyl butyrol \\
\hline Cells, type & $N$ on $P$ & $N$ on $P$ & $P$ on $\mathrm{N}$ & $N$ on $P$ \\
\hline diameter & $56 \mathrm{mag}$ & $75 \mathrm{~mm}$ & $100 \mathrm{~mm}$ & $50 \mathrm{~mm}$ \\
\hline $\begin{array}{l}\text { thickness } \\
\text { number (full s1ze) }\end{array}$ & $\begin{array}{l}0.042 \mathrm{~nm} \\
44\end{array}$ & $0.042 \mathrm{~mm}$ & $0.042 \mathrm{~mm}$ & $0.042 \mathrm{~mm}$ \\
\hline number (wini-rrudule) & 24 & 12 & 8 & 24 \\
\hline Cell support & $\begin{array}{l}\text { PVC-coated } \\
\text { fiberglass } \\
\text { mesh. }\end{array}$ & - & - & Polyvinyl butyrol \\
\hline Primer & Dow Corning & $\begin{array}{l}\text { RTV-108 thinned } \\
\text { with MEK }\end{array}$ & $\begin{array}{l}\text { Dow Corning } \\
30-060\end{array}$ & - \\
\hline $\begin{array}{l}\text { Botrom layer/ } \\
\text { support structure }\end{array}$ & $\begin{array}{l}\text { Aluminum } \\
5052-\mathrm{H} 32\end{array}$ & $\begin{array}{l}\text { Flberglass - } \\
\text { reinforced } \\
\text { molyostar cann }\end{array}$ & $\begin{array}{l}\text { White glass } \\
\text { reinforced } \\
\text { polyoovor: }\end{array}$ & Mylar film \\
\hline Cell metallization & $\begin{array}{l}60-40 \mathrm{~Pb}-\mathrm{Sn} \\
\text { solder; pro- } \\
\text { prletary } \\
\text { metal }\end{array}$ & $\begin{array}{l}\text { T1-Pd-Ag metal } \\
\text { Sn contact } \\
\text { areas }\end{array}$ & $\begin{array}{l}60-40 \mathrm{~Pb}-\mathrm{Sn} \\
\text { solder; pro- } \\
\text { prietary } \\
\text { metal }\end{array}$ & $\begin{array}{l}\text { Ag paste, fired } \\
\text { Ag-solder contacts } \\
\text { ( } 5 \% \text { silver) }\end{array}$ \\
\hline$\frac{\text { Ant1-reflection }}{\text { iudiLing }}$ & $\begin{array}{l}\text { Aluminum } \\
\text { oxidee }\end{array}$ & Metal oxide & None & $\mathrm{SrO}_{2}$ \\
\hline
\end{tabular}



For each module, the insulation resistance between the cell terminal leads and the frame and ground plane was measured before and after the test. Leakage current was measured before, during, and after the test.

To perform correlations between test induced degradation and voltage differences between cells with a module, reverse bias voltage measurements were made of each cell. This procedure is described in detail in the appendix.

One module from each of four Block II manufacturers was placed in the humidity chamber in the arrangement shown in Figure 3 . This arrangement was necessitated by the desire to subject the four modules to the same humidity cycle to minimize one kind of variation (test to test) as well as to conserve time and resources. Variations in humidity and temperature exposure because of positional differences (horizontal, vertical, and tilted, top of chamber vs bottom) were assumed to be inconsequential after consultation with facility personnel.

The humidity cycle that was applied to the modules is based on Method 106 of MIL STD 202. The cycle (Figure 4) consisted of a 24-hour preconditioning period at $50^{\circ} \mathrm{C}$ (uncontrolled humidity) followed by ten 24-hour cycles. The testing was performed in three ten-day periods, with a visual and electrical evaluation following each ten-day test. The Phase 1 and Phase 2 tests were performed at JPL's environmental test facility (Building 144) using the Conrad II humidity chamber.

\section{B. PHASE 2 TESTING}

The second phase of bias-humidity testing of solar modules was conducted to determine if the first phase observations could be repeated and to determine which of the various electrical test parameters were the most significant in producing the observed changes. The second phase tests were conducted in two parts. The first, lasting ten days, exposed the modules to the ground plane bias field only (both polarities) without reverse biasing the cells. During the second ten-day test, modules were forward and reverse biased. Control samples from each manufacturer were included in the environmental chamber during each test. These control samples had no ground plane or bias voltage applied.

Three mini-modules from each of the four Block II manufacturers were placed in the humidity chamber on a special rack as shown in Figure 5. The rack permitted the modules to be tilted at an angle of $60^{\circ}$.

The electrical connections for the first test are shown in Figure 6. All four manufacturers' samples were connected as shown except that the modules from manufacturer L had a partial ground plane on the back side of the cells in addition to the top surface ground planes. These top surface ground planes covered the entire top surface of the modules, rather than half the surface as was done for the Phase 1 tests. They were constructed of an open mesh screening, 


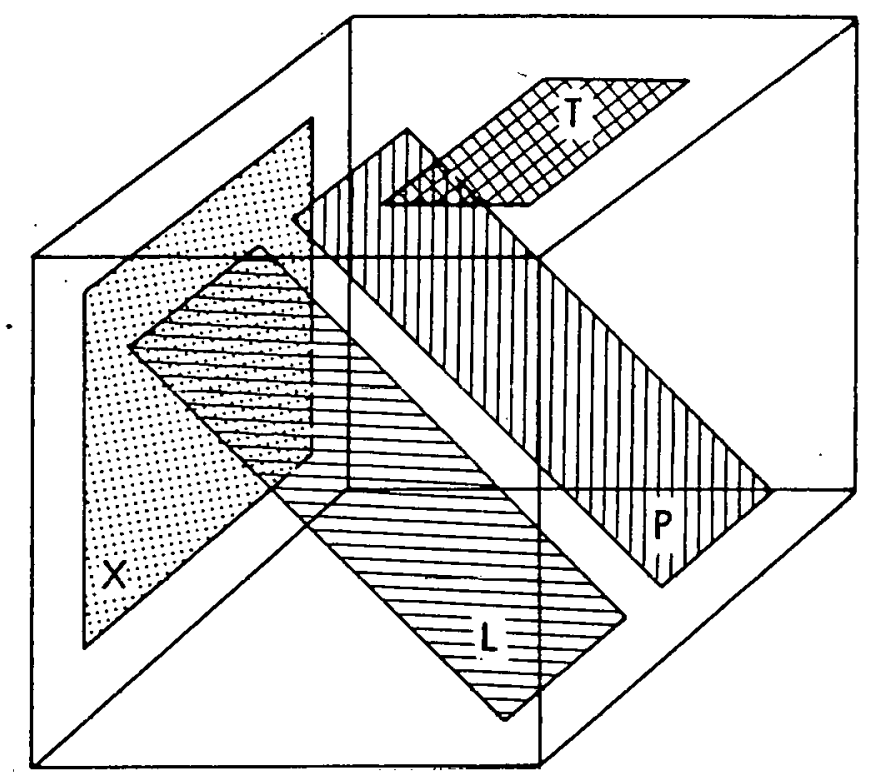

HUMIDITY CHAMBER

Figure 3. Arrangement of Ful1-Sized Modules in Chamber for Phase 1 Tests

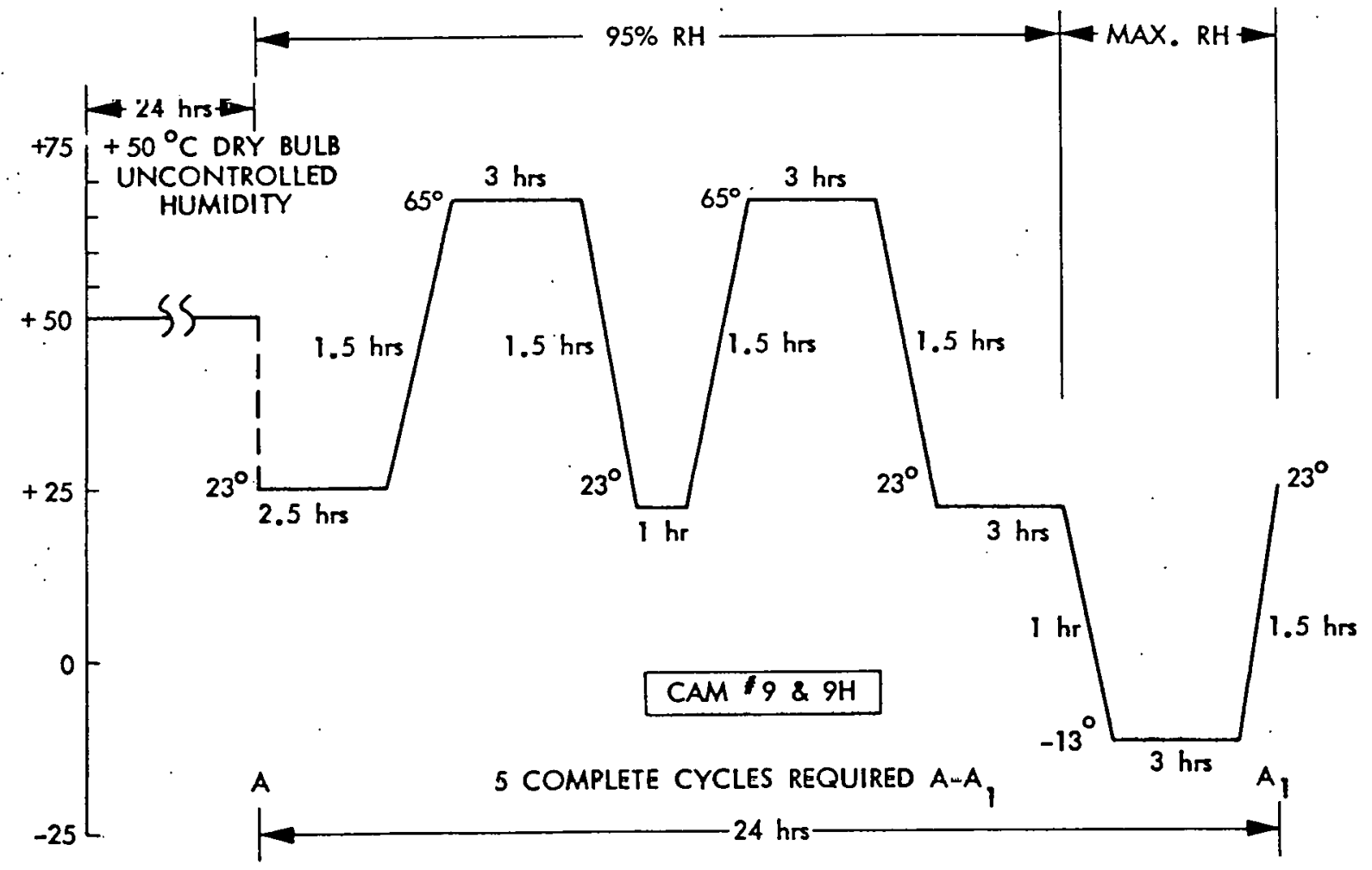

(HUMIDITY/FREEZING PROFILE)

Figure 4. Temperature-Humidity Test Profile 


\section{$5101-84$}

rather than perforated metal, to permit exposure of more of the top surface to the chamber environment. The ground plane screen was in direct contact with the module top surfaces, and electrically connected to the metal frame of the modules from manufacturers $\mathrm{L}, \mathrm{T}$, and $\mathrm{X}$.

The electrical connections for the second ten-day test of Phase 2 were as shown in Figure 7.

Data measurement methods of the Phase 2 tests were similar to those for Phase 1, i.e., I-V curves, visual inspection, and cell reverse bias voltage. The temperature-humidity profile for both of the Phase 2 tests was the same as for the earlier Phase 1 tests (Figure 4).

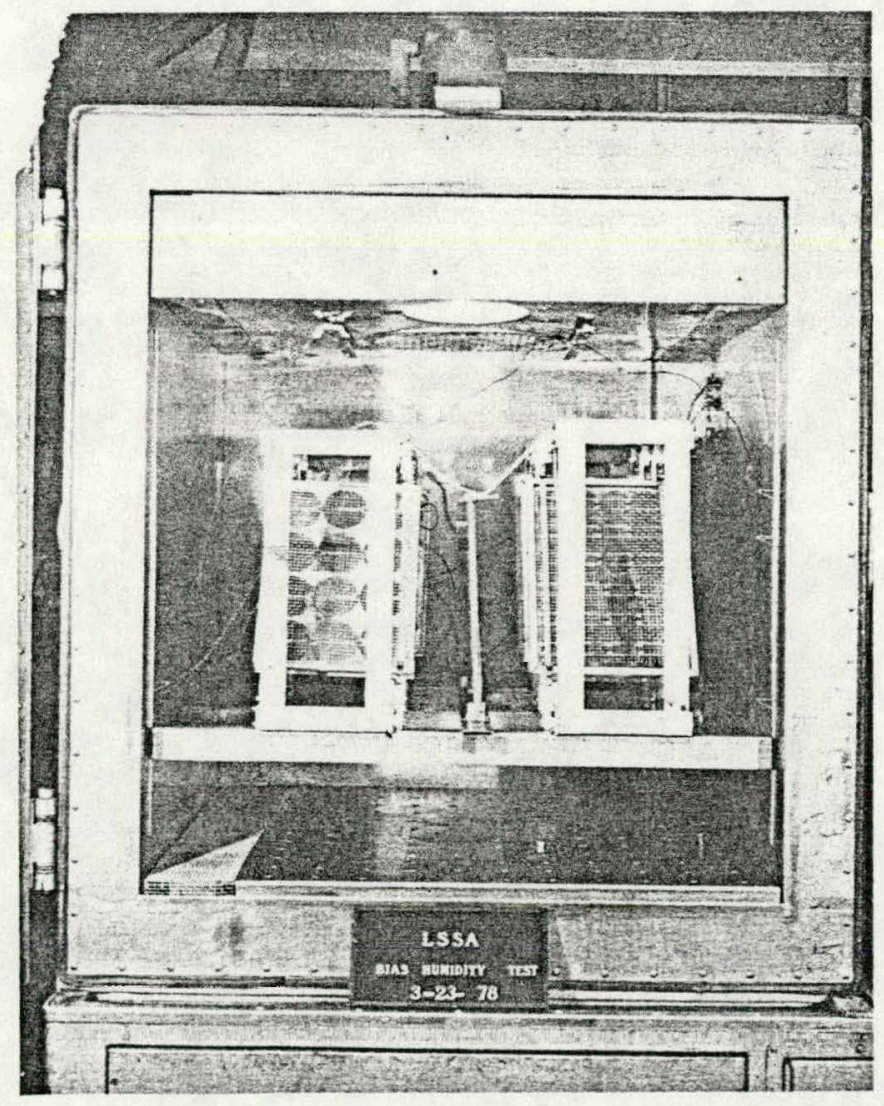

Figure 5. Mini-Modules in Environmental Chamber at Start of Phase 1 Tests 


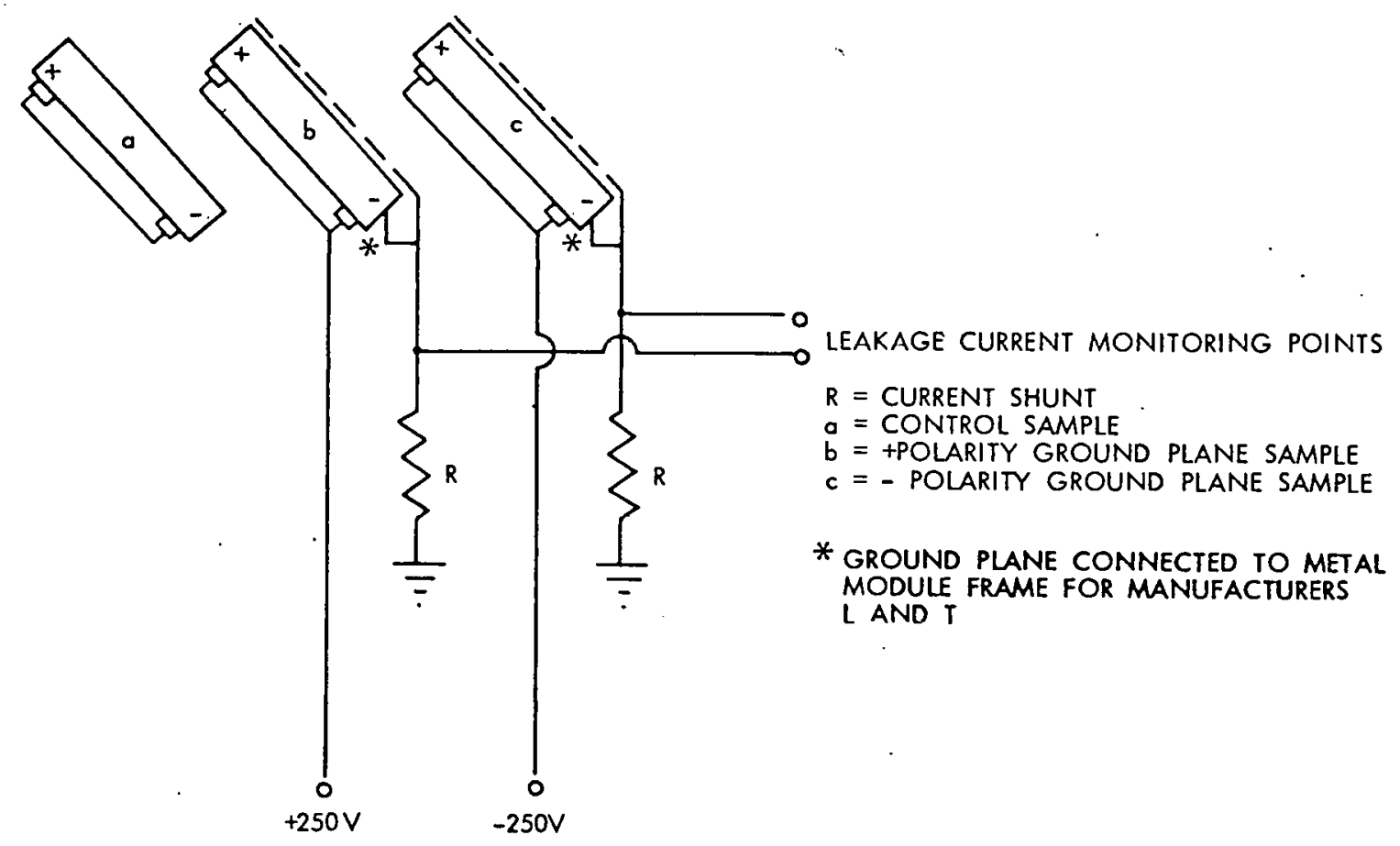

Figure 6. Electrical Connections for Phase 2 Ground Plane Effects
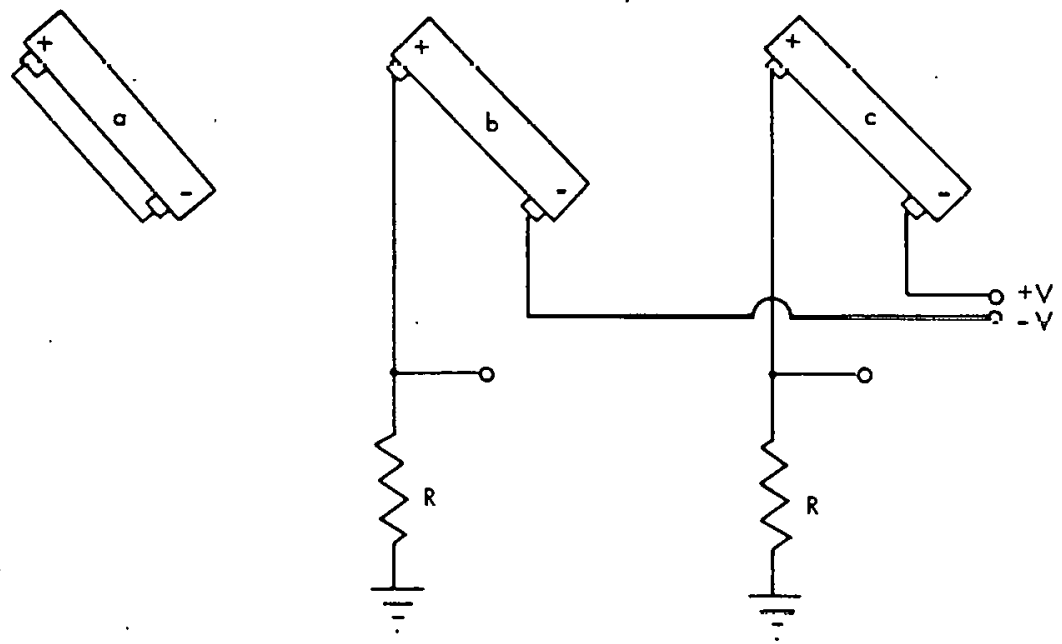

$R=$ CURRENT SHUNT

$V=$ FORWARD OR REVERSE BIAS VOLTAGE

0 CONTROL SAMPLE

$\vec{b}=$ REVERSE BIAS, WITHOUT GROUND PLANE

$c=$ FORWARD BIAS, WITHOUT GROUND PLANE

Figure 7. Electrical Connections for Phase 2 Cell Bias Effects 
Following each of the ten-day bias-humidity tests, the modules were examined, photographed, and tested. Changes were classified, when possible, as:

(a) Changes related to a particular bias condition.

(b) Changes not associated with bias.

\section{A. PHASE 1 TEST RESULTS}

1. Visible Changes

Two of the four modules from Phase I showed visible changes associated with material transfer and discoloration. Visible deterioration of the front surface appeared after the first ten-day test on the module from manufacturer P. However, no appreciable changes were noted as a result of subsequent testing. All cells exhibited a white material extending out across the cell surface from the metallization fingers. On some of the white material, a dendritic structure was observed. Using an energy dispersive $X$-ray analyzer (EDAX), the major constituent of the white surface material, including the dendritic growth, was identified as tin. Other than some traces of lead, no other elements were detected. The corrosion mechanism appears to be a tin migration effect. Figures 8 and 9 show SEM views of typical areas, including a dendritic growth.

The second module having visual changes was from manufacturer L. The metallization fingers on top of the cells and the back contacts were discolored to a yellow-brown appearance around the edges of the cells. This yellow-brown discoloration was noted after the second ten-day exposure (i.e., twenty days). There was additional discoloration present after the third ten-day exposure. As part of the failure analysis, portions of the bottom encapsulant were peeled off the hark of nne representative cell. It wac obocrved that the yellow-brown discoloration peeled off with the encapsulant, leaving a normal silver color on the cell back contact.

Using the crystal spectrometer, wavelength dispersive X-ray analyzer (WDXA), the major constitutent of the yellow-brown material was found to be silver with minor traces of lead and sulfur. The corrosion mechanism appears to be a silver tarnishing or oxidation effect.

No visible changes were noted on the modules from manufacturers $\mathrm{T}$ and $\mathrm{X}$.

2. Electrical Measurements

The hias-humidity test had little effect on power output. The 


\section{$5101-84$}

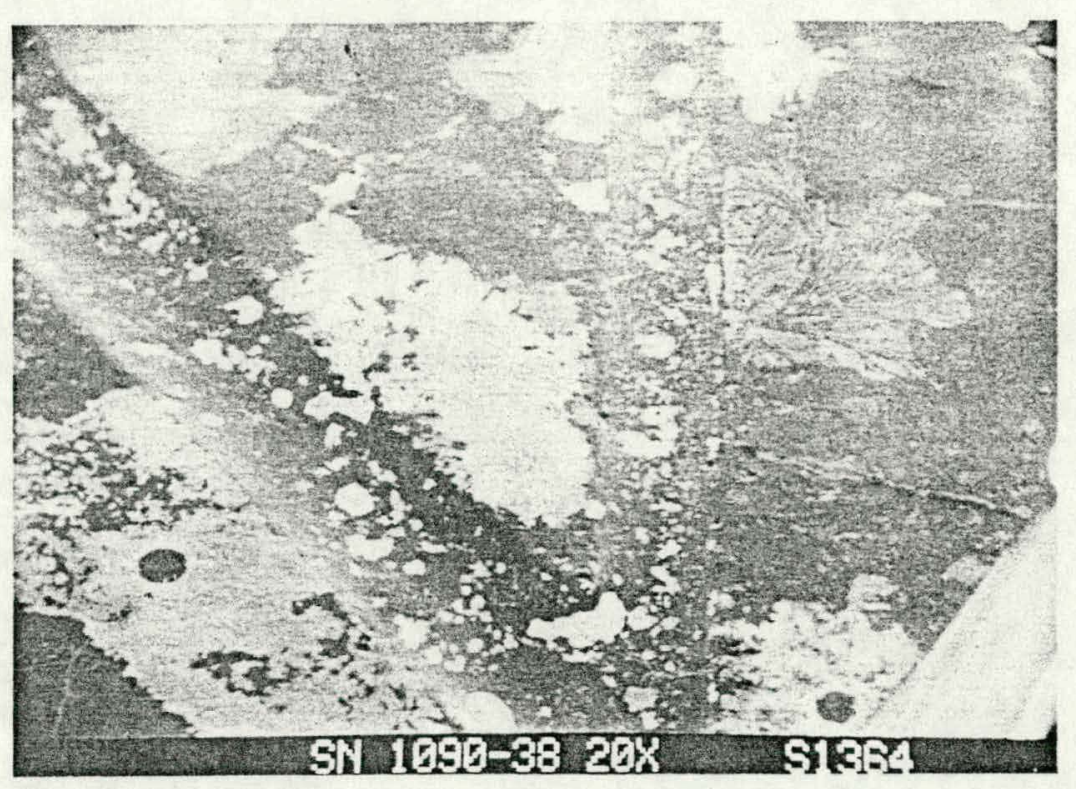

Figure 8. SEM View of Cell No. 38 Showing Various Forms of Corrosion Products. Tin was the Major Constituent of All Corrosion Products Examined

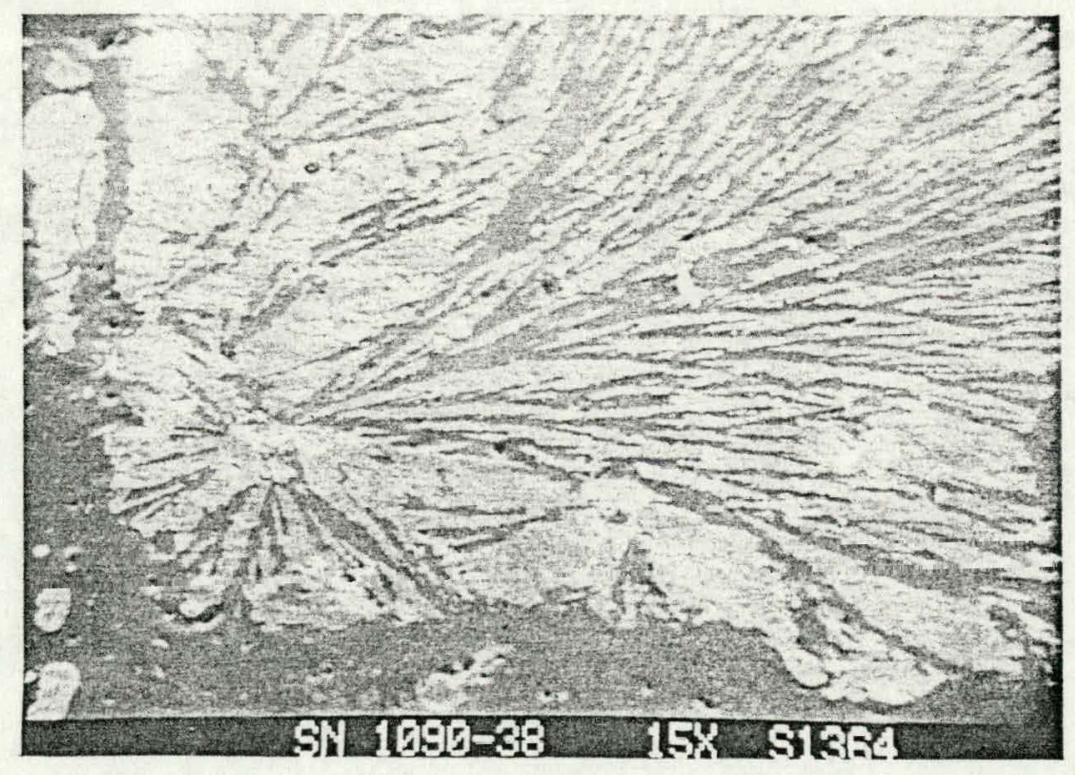

Figure 9. Dendritic Growth Pattern on Cell No. 38 
maximum power loss noted on any module, even after thirty days exposure, was $5 \%$. The power measurements taken during the Phase 1 test are given in Table 3 . Assuming a measurement accuracy of $\pm 2 \%$, the only modules with notable power changes were from manufacturer $T$ (3\%) and manufacturer $L(5 \%)$. The Phase 1 test results and test conditions are summarized in Table 4.

Table 3. Maximum Power Measurements, Phase 1

\begin{tabular}{|c|c|c|c|c|c|c|c|c|c|c|c|}
\hline \multirow{2}{*}{ Module } & \multirow{2}{*}{$\begin{array}{l}\text { Inftial } \\
\text { Output } \\
\text { (Watts) }\end{array}$} & \multicolumn{2}{|c|}{ Post 10-day humidity } & \multicolumn{4}{|c|}{ Post 20-day humidity } & \multicolumn{4}{|c|}{. Post 30-day humidity } \\
\hline & & Dry & Delta & Wet & Delta & Dry & Delta & Wet & Delta & Dry & Delta \\
\hline $\mathrm{T}$ & 11.23 & 10.99 & $-2.1 \%$ & 10.96 & -2.42 & 10.92 & $-2.7 \%$ & 10.96 & $-2.4 \%$ & 11.08 & $-1.3 \%$ \\
\hline L & 27.14 & 26.57 & $-2.1 \%$ & 26.48 & $-2.4 \%$ & 26.39 & $-2.8 \%$ & 25.59 & $-5.7 \%$ & 25.70 & $-5.3 \%$ \\
\hline$x$ & 20.50 & 20.48 & $-0.1 \%$ & 20.31 & $-0.9 \%$ & 20.35 & $-0.7 \%$ & 20.32 & $-0.9 \%$ & 20.50 & $0.0 \%$ \\
\hline $\mathrm{P}$ & 33.71 & 34.17 & $+1.4 \%$ & 32.18 & $-4.5 \%$ & 33.62 & $-0.3 \%$ & 31.88 & $-5.4 \%$ & 33.57 & $-0.4 \%$ \\
\hline
\end{tabular}

${ }^{*}$ Fu11 s1ze.

B. PHASE 2 TEST RESULTS

1. Visible Changes

The visible changes observed as a result of the Phase 2 biashumidity testing were similar to those noted during Phase I.

Some discoloration appeared on the cells of the mini-modules from manufacturer $P$ which was similar in appcarance to the tin migration observed following the first phase tests. This was randomly distributed, not affecting all cells on any mini-module, and was most extensive on the unbiased control sample. The changes were barely visible after the first ten-day test, but clearly evident after the second test. Figures 10 and 11 show the worst area from the unbiased control sample. By SEM-EDAX, the material between the metallization fingers was found to be rich in tin, similar to the observation on the first phase bias-humidity test.

A yellow discoloration of the edges of the front and back contact metallization was observed on one of the three mini-modules from manufacturer $L$, after the first ten-day test. This mini-module had +250 volts on the cells, with the ground planes (covering both the front and rear faces of the mini-module) at ground potential. No other appreciable changes were observed on any other of the mini modules, and the discoloration did not appear to increase during the second ten-day test. This discoloration was very similar to that 
Table 4. Summary of Phase 1 Bias-Humidity Test Results

\begin{tabular}{|c|c|c|c|c|}
\hline \multirow[b]{3}{*}{ Test Results } & \multicolumn{4}{|c|}{ MANUFACTURER } \\
\hline & $\mathrm{T}$ & $\mathrm{x}$ & $\mathrm{P}$ & L \\
\hline & & & & \\
\hline $\begin{array}{l}\text { a) Visual Changes } \\
\text { b) Power Output } \\
\text { Changes }\end{array}$ & $-3 \%$ & $\begin{array}{l}\text { None } \\
\text { None }\end{array}$ & $\begin{array}{l}\text { Tin migration } \\
\text { on top of cells } \\
\text { None }\end{array}$ & $\begin{array}{l}\text { Discoloration } \\
\text { on bottom of } \\
\text { cells } \\
-5 \%\end{array}$ \\
\hline Test Conditions & & & & \\
\hline $\begin{array}{l}\text { Position in } \\
\text { Chamber }\end{array}$ & Horizontal & Vertical & Tilted & Tilted \\
\hline $\begin{array}{l}\text { Reverse Bias } \\
\text { Voltage }\end{array}$ & $250 \mathrm{~V}$ & None & $250 \mathrm{~V}$ & $250 \mathrm{~V}$ \\
\hline Bias Current & $6.1 \mathrm{~mA}$ & None & $5.8 \mathrm{~mA}$ & $100 \mathrm{~mA}$ \\
\hline Ground Plane & $\begin{array}{l}\text { Half of } \\
\text { top }\end{array}$ & $\begin{array}{l}\text { All of } \\
\text { top }\end{array}$ & Half of top & $\begin{array}{l}\text { Half of } \\
\text { bottom }\end{array}$ \\
\hline
\end{tabular}

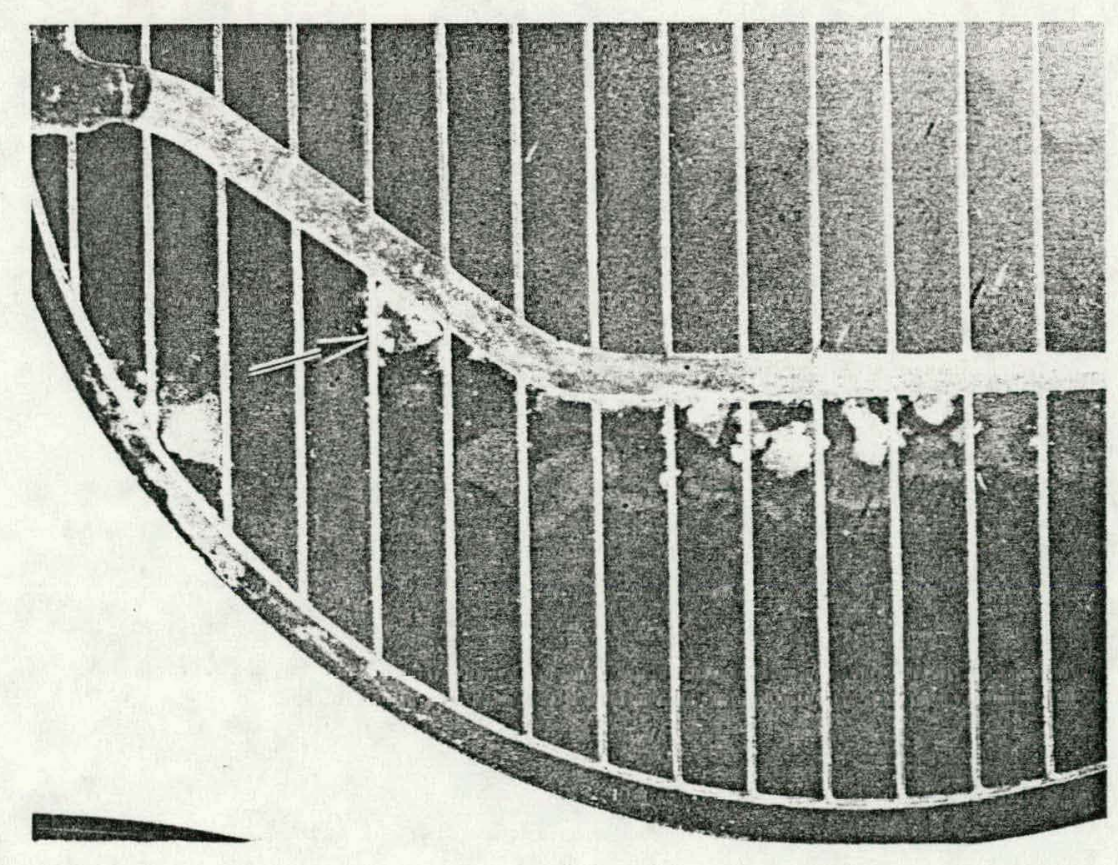

Figure 10. Example of Tin Migration on Solar Cell After Bias-Humidity Testing, Phase 2. Arrow Indicates Area Shown in Figure 11 


\section{$5101-84$}

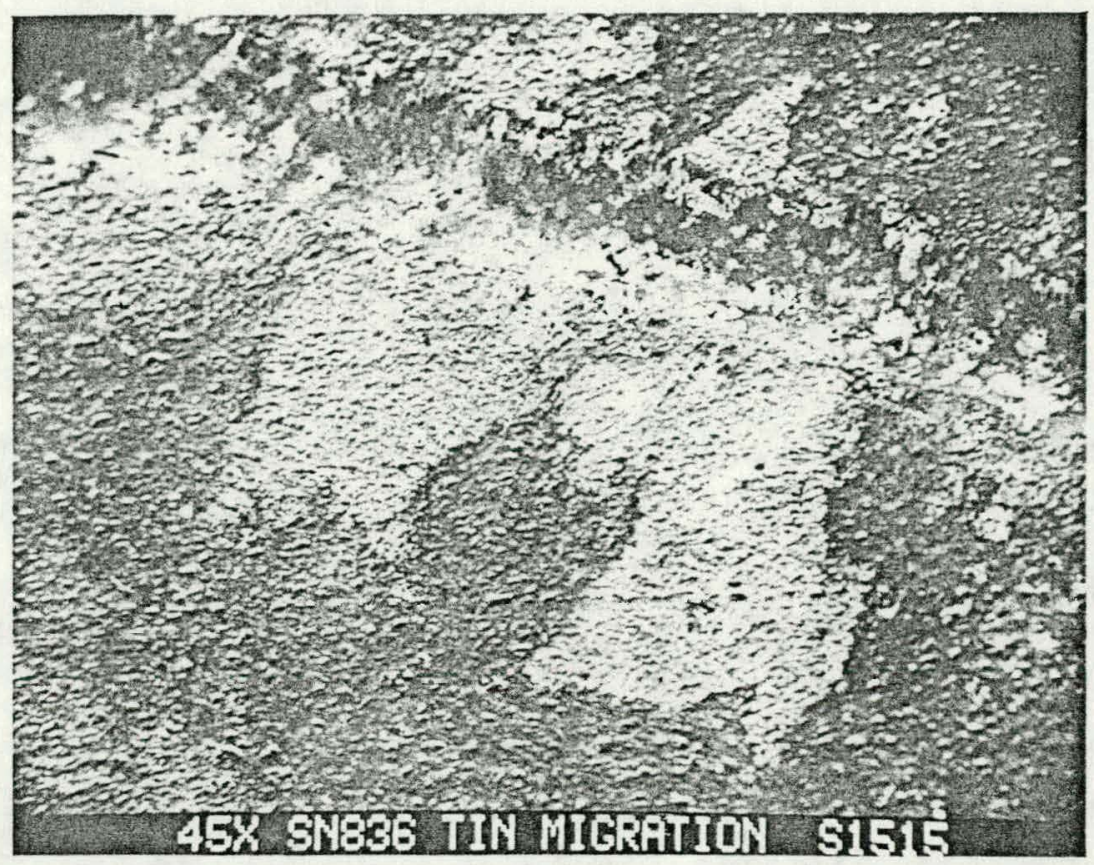

Figure 11. Scanning Electron Microscope View of Tin Migration After Bias-Humidity Testing, Phase 2

observed on the first phase bias-humidity test of a module from manufacturer $L$. It was also the only observed change on any of the second phase modules which may be related to a particular bias condition.

Some discoloration or delamination of the encapsulant was noted on many cells of the modules from manufacturer $T$, particularly after the second ten-day test. None of the changes appeared to be related to bias voltage.

No appearance changes were noted on the mini-modules from manufacturcr $\mathrm{X}$.

\section{Electrical Measurements}

The results for Phase 2 testing were similar to Phase 1 . The test had little effect on power output. The maximum power change observed on any of the Phase 2 bias-humidity mini-modules, with one exception, was $3 \%$. The one exception was observed after the second ten-day test when a crack in one cell of a mini-module isolated half the cell and caused a $34 \%$ power loss. The Large Area Pulsed Solar Simulator (LAPSS) test data for modules exposed to the Phase 2 biashumidity tests is presented in Table 5. A summary of the Phase 2 bias-humidity test results and test conditions is given in Table 6 .

\section{Delamination Test Module}

A full sized field module (manufacturer P) from MIT, Lincoln Laboratory, with extensive encapsulation delamination was exposed to 
Table 5. Electrical Measurements for Bias-Humidity Tests, Phase 2

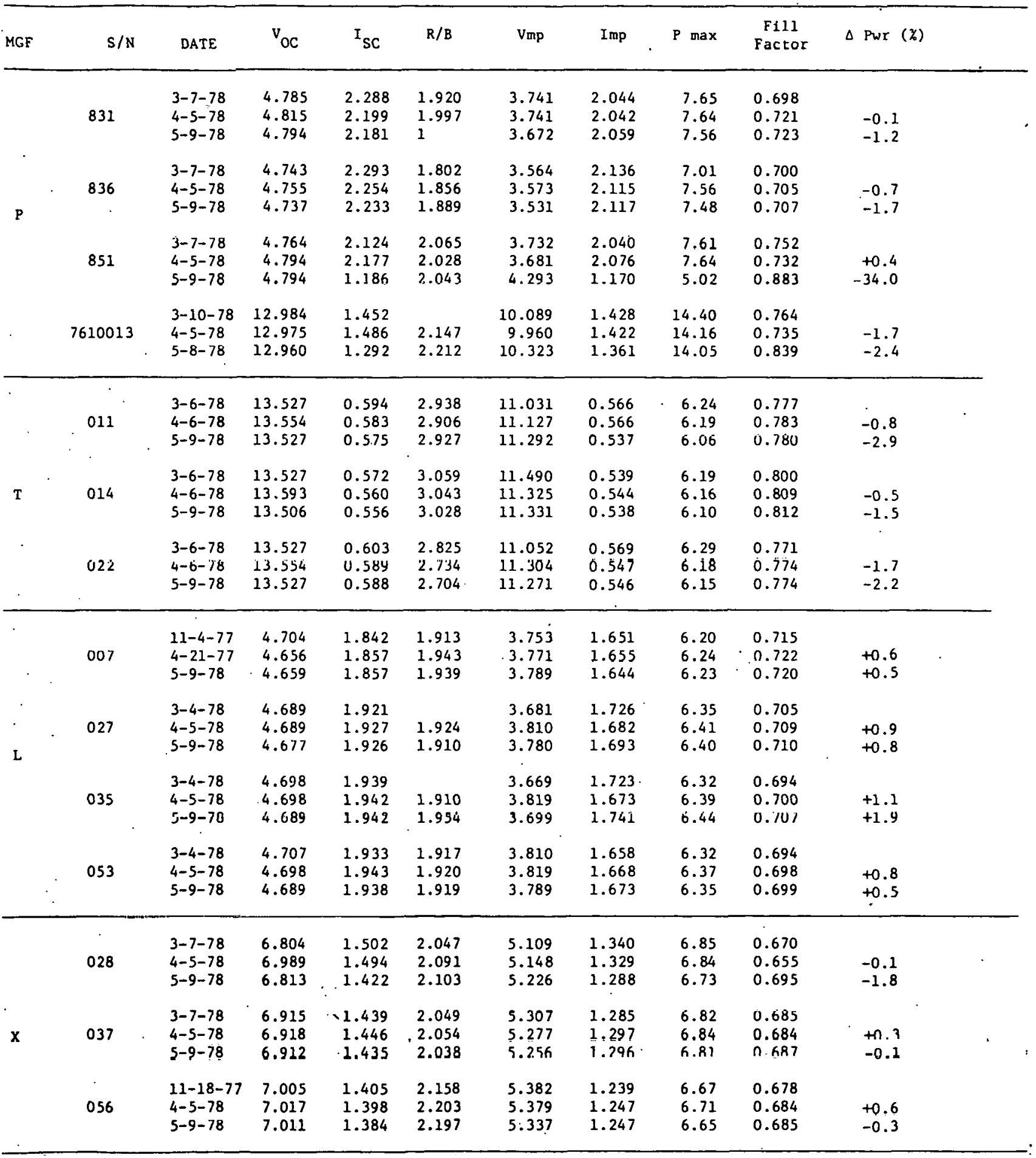


Table 6. Summary of Phase 2 Bias-Humidity Test Results

\begin{tabular}{|c|c|c|c|c|c|c|c|c|c|c|c|c|c|c|}
\hline \multirow{2}{*}{$\begin{array}{l}\text { MANUFACTLRER } \\
\text { SERIAL NLMBER }\end{array}$} & \multicolumn{3}{|c|}{$\mathrm{T}$} & \multicolumn{3}{|c|}{$\mathrm{x}$} & \multicolumn{4}{|l|}{$r$} & \multicolumn{4}{|c|}{$\mathrm{L}$} \\
\hline & 911 & 022 & 014 & 056 & (137 & $028:$ & 836 & 851 & 831 & (1) & $027^{\circ}$ & 053 & 035 & 007 \\
\hline \multicolumn{15}{|l|}{ Test Results } \\
\hline a) Visual =hanges & $\begin{array}{l}\text { Some } \\
\text { tion } \\
\text { tion }\end{array}$ & $\begin{array}{l}\text { disco } \\
\text { or de }\end{array}$ & $\begin{array}{l}\text { lora- } \\
\text { lamina- }\end{array}$ & None & None & None & \multicolumn{3}{|c|}{$\begin{array}{l}\text { Some tin migra- } \\
\text { tion on top of } \\
\text { cells } \\
\qquad\left|\begin{array}{l}\text { cracked } \\
\text { cell }\end{array}\right|\end{array}$} & $\begin{array}{l}\text { See } \\
\text { text }\end{array}$ & None & None & $\begin{array}{l}\text { Discolor- } \\
\text { ation on } \\
\text { bottom of } \\
\text { cells }\end{array}$ & None \\
\hline $\begin{array}{l}\text { b) Power output } \\
\text { changes }\end{array}$ & $-3 \%$ & $-2 \%$ & $-2 \%$ & None & None & $-2 \%$ & $-2 \%$ & $-34 \%$ & $-1 \%$ & $-2 \%$ & None & None & $+2 \%$ & None \\
\hline Test Conditions (2) & & & & & & & & & & & . & . & & \\
\hline $\begin{array}{l}\text { Module Voltage ( } 3) \\
\text { (1st 10-day test) }\end{array}$ & 0 & $-250 \mathrm{~V}$ & $+2 \mathrm{~s} .0 \mathrm{~V}$ & 0 & $-250 \mathrm{~V}$ & $+250 \mathrm{~V}$ & 0 & $-250 \mathrm{~V}$ & $+250 \mathrm{~V}$ & $+250 \mathrm{~V}$ & 0 & $-250 \mathrm{~V}$ & $+250 \mathrm{~V}$ & (4) \\
\hline $\begin{array}{l}\text { B1as Voltage: (5) } \\
\text { (2nd 10-day test) }\end{array}$ & 0 & $\begin{array}{l}\text { i20v } \\
\text { rev }\end{array}$ & $\begin{array}{l}10 \mathrm{v} \\
\text { fwid }\end{array}$ & 0 & $\begin{array}{l}3.5 v \\
\text { fwd }\end{array}$ & $\begin{array}{l}30 j \\
\text { rej }\end{array}$ & 0 & $\begin{array}{r}3.5 \mathrm{~V} \\
\mathrm{fwd}\end{array}$ & $\begin{array}{l}120 \mathrm{~V} \\
\text { rev }\end{array}$ & 0 & 0 & $\begin{array}{l}1.5 \mathrm{~V} \\
\text { fwd }\end{array}$ & 0 & $\begin{array}{l}3.5 \mathrm{~V} \\
\text { rev }\end{array}$ \\
\hline $\begin{array}{l}\text { Bias Current } \\
\text { (2nd 10-day test) }\end{array}$ & - & $9.1 \mathrm{~mA}$ & $6.5 \mathrm{nA}$ & - & $11.6 \mathrm{~mA}$ & $13.8 \mathrm{~mA}$ & - & $5.0 \mathrm{~mA}$ & $5.7 \mathrm{~mA}$ & - & - & $16.2 \mathrm{~mA}$ & - & $16.4 \mathrm{~mA}$ \\
\hline
\end{tabular}

Notes: (1) Delamination test module, full size fleld module from MIT/LL, S/N 7610013.

(2) All modules tilted $60^{\circ} \mathrm{f}=\mathrm{om}$ horizontal.

(3) V.oltage applied to the cell string (both terminals shorted). Ground planes connected to ground througi current sensing resistors $(1 \mathrm{k} \Omega)$.

(4) $S !$ N 007 not exposed to first 10-day test.

(5) Measured at $21^{\circ} \mathrm{C}$ following 24-hour condi:ionting pertod. 
the humidity cycle during the Phase 2 tests. The rationale for this concurrent test was to determine whether humidity cycling coupled with a ground plane would significantly accelerate delamination of an existing condition. For the ground plane effect test, a ground plane was placed over the front face of the module and a potential of $+250 \mathrm{~V}$ was applied to the terminals. For the second test, the terminals were short circuited.

No significant acceleration of the existing delamination was observed. The delamination areas increased somewhat in area, and a distinct color change, from green toward a bleached yellow-green, was noted on the fiberglass substrate. Immediately following the second ten-day test, the delamination areas were observed to be puffy, and apparently. filled with water. This feature disappeared within one or two days as the module dried out. No corrosion or tin migration was observed. The output power was moderately decreased during the biashumidity test (down $2.4 \%$ ), and short circuit current was reduced.

\section{CELL EQUIVALENT SHUNT RESISTANCE RESULTS}

To perform correlations between test induced degradation and voltage differences between cells with a module, reverse bias voltage measurements were made of each cell using the shadowing technique described in the appendix. Using the calculation method, also given in the appendix, cell shunt resistance was determined. The significance of cell shunt resistance is that the voltage difference from cell to cell with reverse biasing is proportional to shunt resistance $\left(E=I R_{S H}\right)$. Consequently, a cell with a high shunt resistance would experience a higher bias voltage across the cell during the bias humidity test than a cell with lower shunt resistance.

Figure 12 showe the variation of cell shunc resistances within a module and among modules. The cell shunt resistances from one manufacturer's modules are significantly different from the resistances of the other three. This is probably due to process differences between the manufacturers. The significance of this difference to bias voltage testing, such as bias-humidity, is that complexities in the test set up and equipment must be introduced and that test tailoring for each manufacturer's modules may be warranted. Specifically, a universal test requirement and test set up may be difficult to specify.

Two difficulties were experienced in performing these measurements. First, it was found that significant light leakage to the shadowed cell could occur because of reflections from the substrate and oblique illumination. These effects were minimized by an improved shaduw mask; to compensate for any remaining "biao current" effect, a 5-10mA correction factor was applied.

The second difficulty arises from the non-linear nature of the reverse bias $I-V$ curve. This is illustrated by Figure 13. The two reverse bias curves shown were made by direct probing across the shadowed cells with only normal room light as a background (much lower intensity than the Sun-u-lator). It may be seen that the calculated 


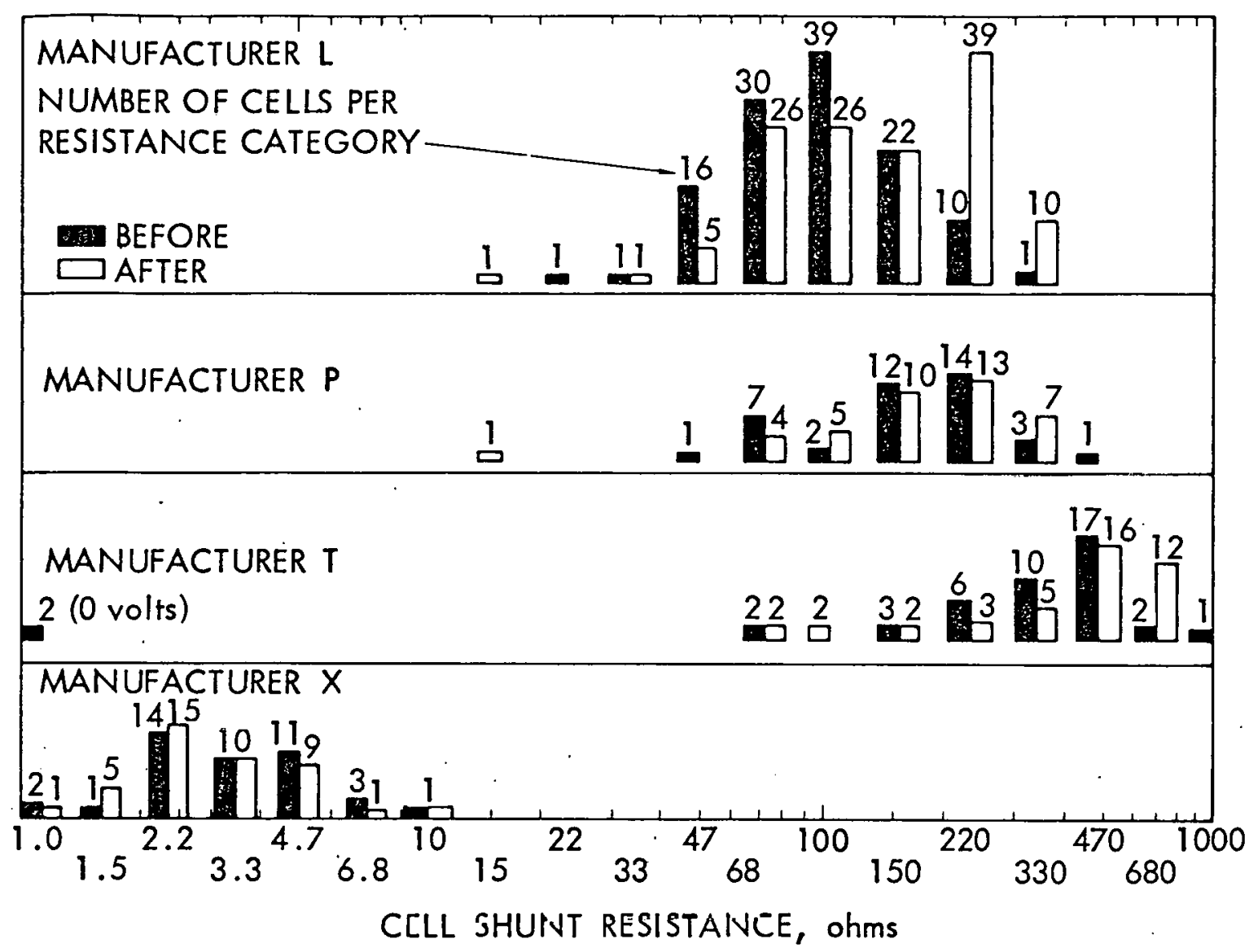

Figure 12. Cel1 Shunt Resistance Before and After Bias-Humidity Testing, Phase 1

resistance value changes drastically with the selected current level. Therefore, the data presented here for $100 \mathrm{~mA}$ reverse bias current may be taken as only one point on a curve, and the term "equivalent shunt resistance" (ESR) is used to emphasize this fact. The actual shunt resistance usually is considerably higher (if taken as the slope of the I-V curve near the origin), and the limiting value of reverse bias voltage at high currents (over $500 \mathrm{~mA}$ ) would correspond to a much lower equivalent shunt resistance. It was observed that some $I-V$ curves may cross, so that a cell with higher than average ESR at low current (50-100mA) may have a lower limiting value of high current reverse bias voltage than other cells with lower ESR. (See Figure 14.)

Following the shadowing technique measurements, the reverse $I-V$ characteristics of the same cells were recorded by direct probing using a four point probe system, and with electronic voltmeter, ammeters, and an $X-Y$ plotter. The wide range of reverse characteristics of individual cells within a module is well illustrated by this rechnique (Figures 14 and 15 ). 


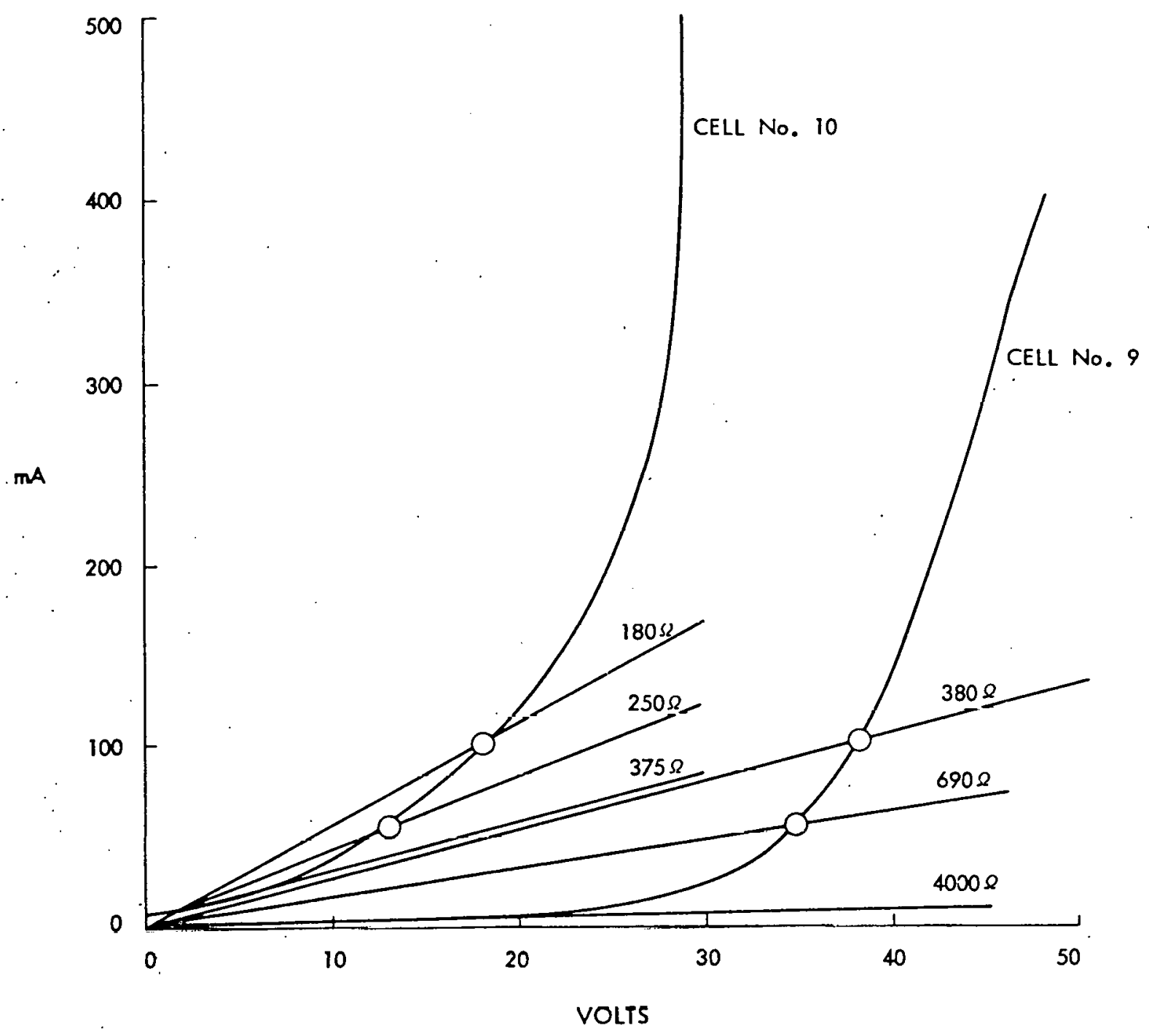

Figure 13. Examples of Reverse Bias I-V Curves for Two Typical Cells 


\section{$5101-84$}

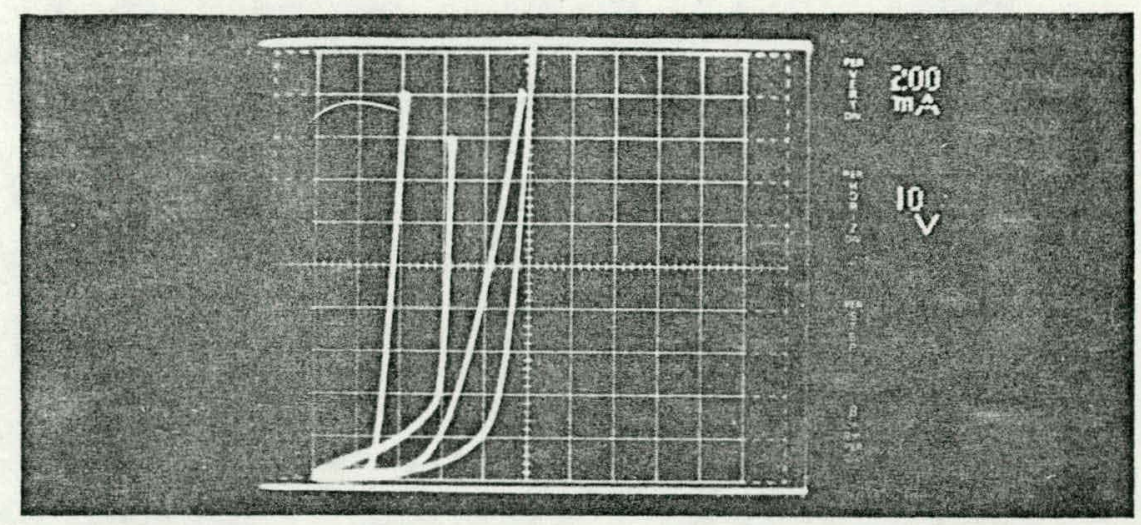

Figure 14. Curve Tracer Trace of Reverse Bias Characteristics of Four Cells. Note that Curves May Cross, and a Wide Range of Limiting Voltages Was Encountered

Table 7 lists the calculated ESR at $100 \mathrm{~mA}$ for all cells from two modules used during the Phase 1 bias humidity testing. The data has been corrected for the 5-10mA "bias current" effect, and compared with direct curve tracer measurements. Approximate ESR values from direct curve tracer measurements are also included. In general, the shadow measurement data agrees well with the curve tracer data, giving increased confidence in the validity of the shadowing technique. Some cases where the curve tracer ESR is significantly higher than the shadow technique value may have been due to contact resistance problems.

No correlations were observed between degree of corrosion, applicd voltage differences from cell to cell, ground plane position, or potential difference between the cell and the ground plane.

\section{MODULE INSULATION AND REVERSE BIAS RESISTANCE RESULTS}

From voltage and current measurements made during the Phase 1 and Phase 2 tests, module insulation resistances and module reverse bias resistances were determined. The insulation resistance for three of the four modules (Phase 1) decreased for the first seven to ten days and then did not change appreciably thereafter (Figure 16). No insulation resistance changes were noted in the module from manufacturer $T$. This data suggests that future test plans for insulation resistance should include test durations of moderate length, e.g. ten days.

Module reverse bias resistance is plotted as a function of time and module temperature in Figures 17 and 18. The data indicate slight increases in reverse bias resistance during the first ten days. The spread in resistance at the hot and cold portions of the cycle varied considerably from manufacturer to manufacturer. In one case, the low temperature condition resulted in higher resistance. In another casc, the higher temperature resulted in somewhat higher resistance. Some 


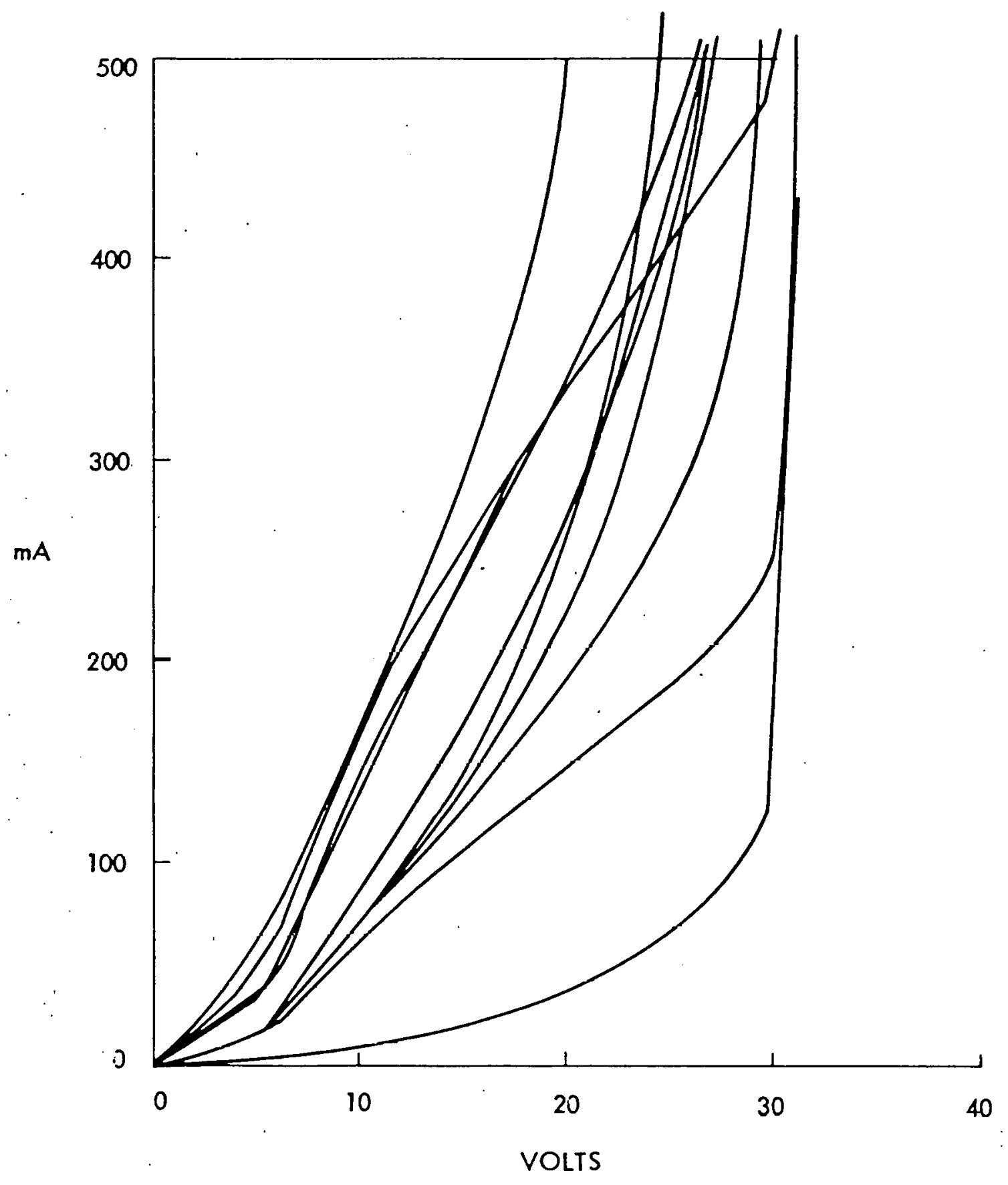

Figure 15. Examples of Reverse Bias I-V Curves for Several Cells Within a Given Module 


\section{$5101-84$}

Table. 7. Comparison of Equivalent Shunt Resistance Results Obtained by Two Different Methods

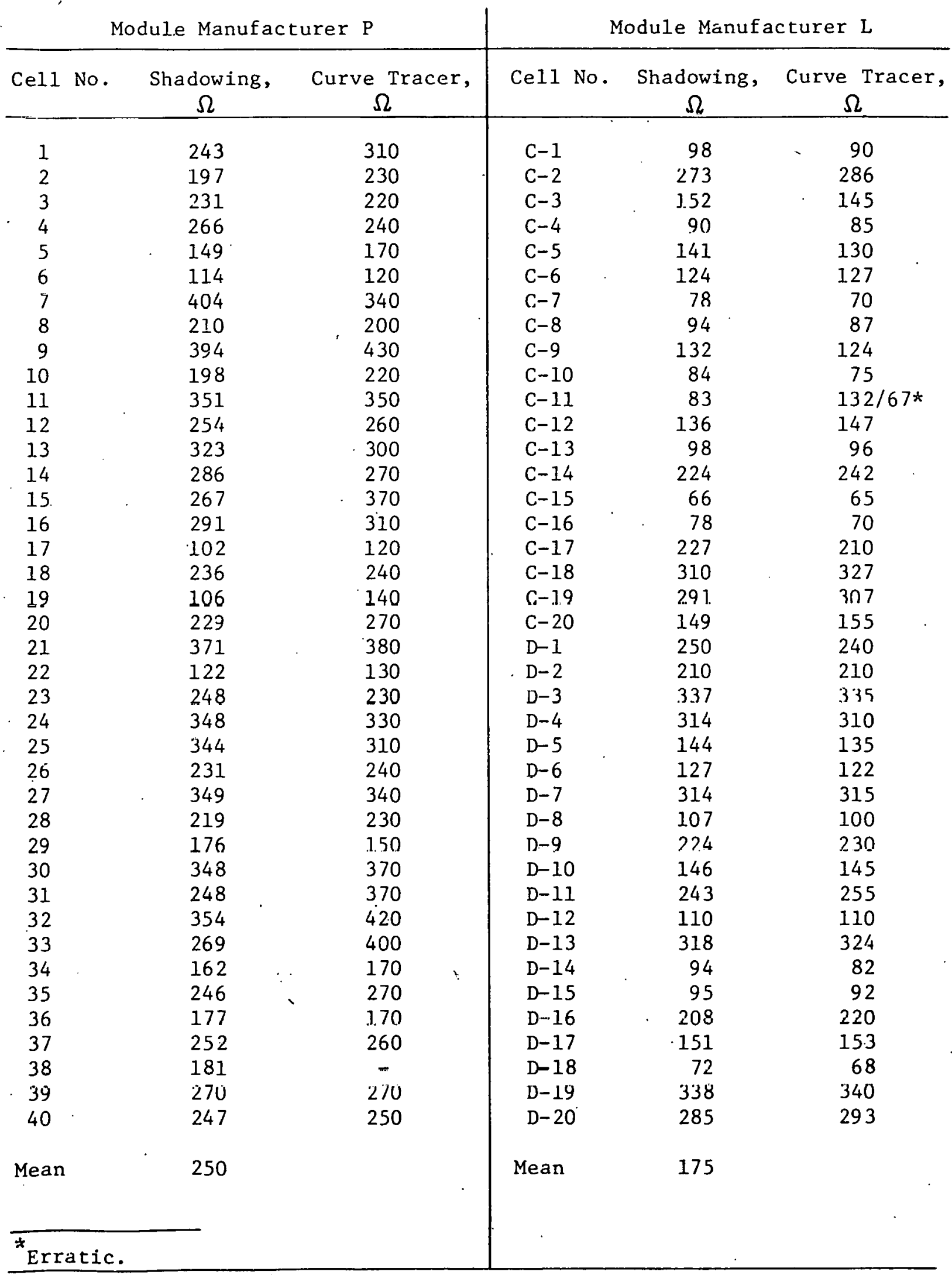


$5101-84$

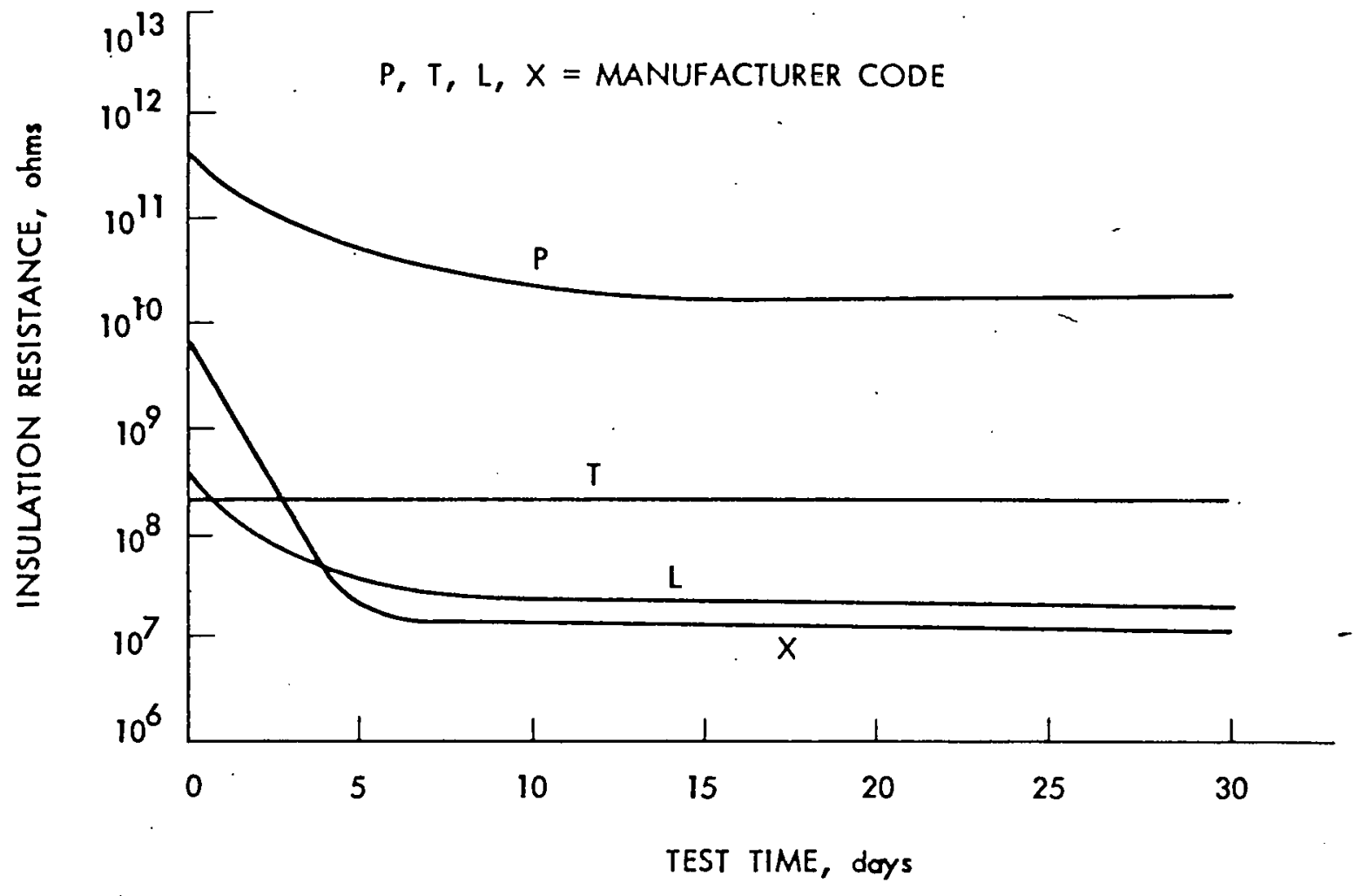

Figure 16. Module. Insulation Resistance, Phase 1

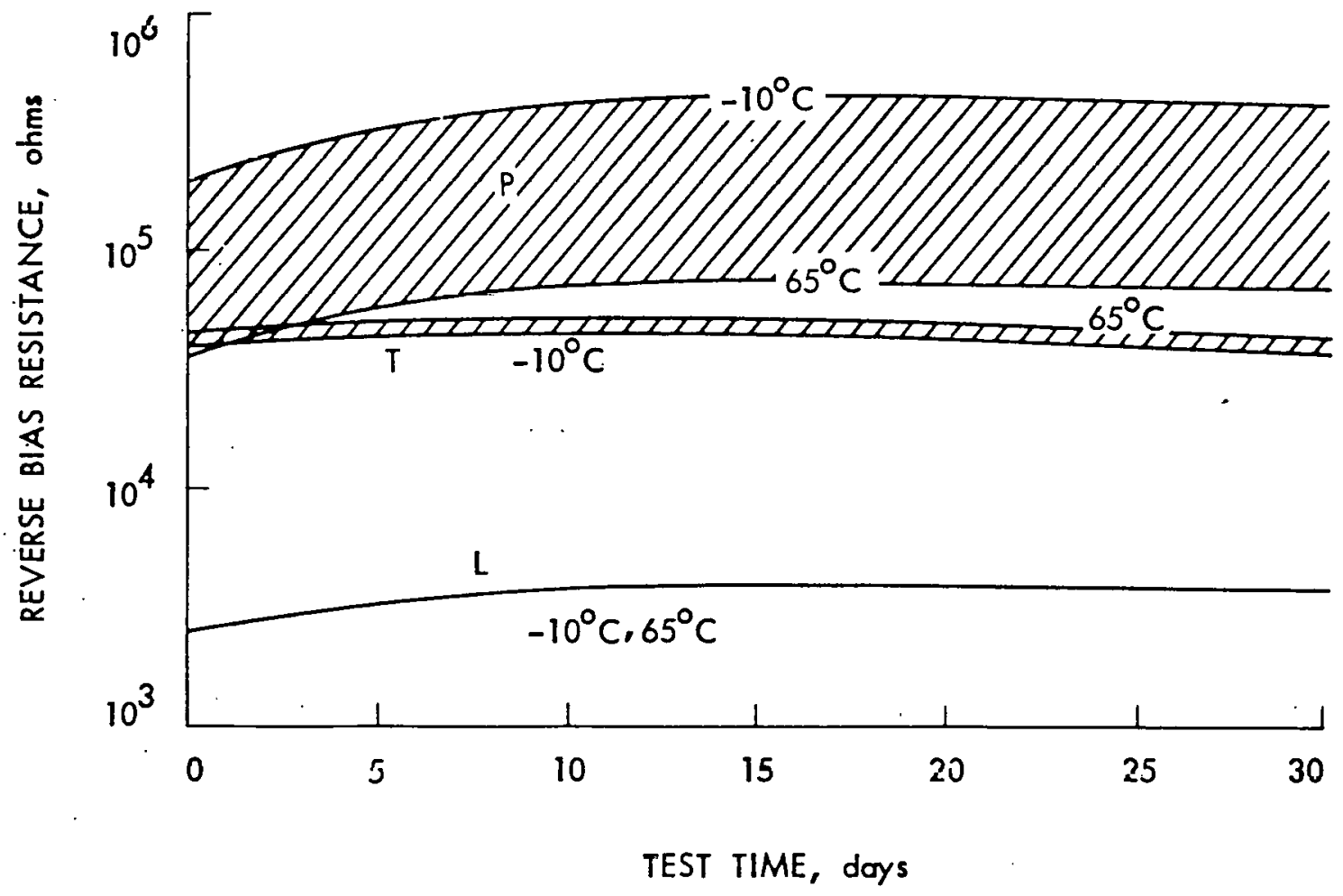

Figure 17. Module Reverse Bias Resislance, Phase 1 


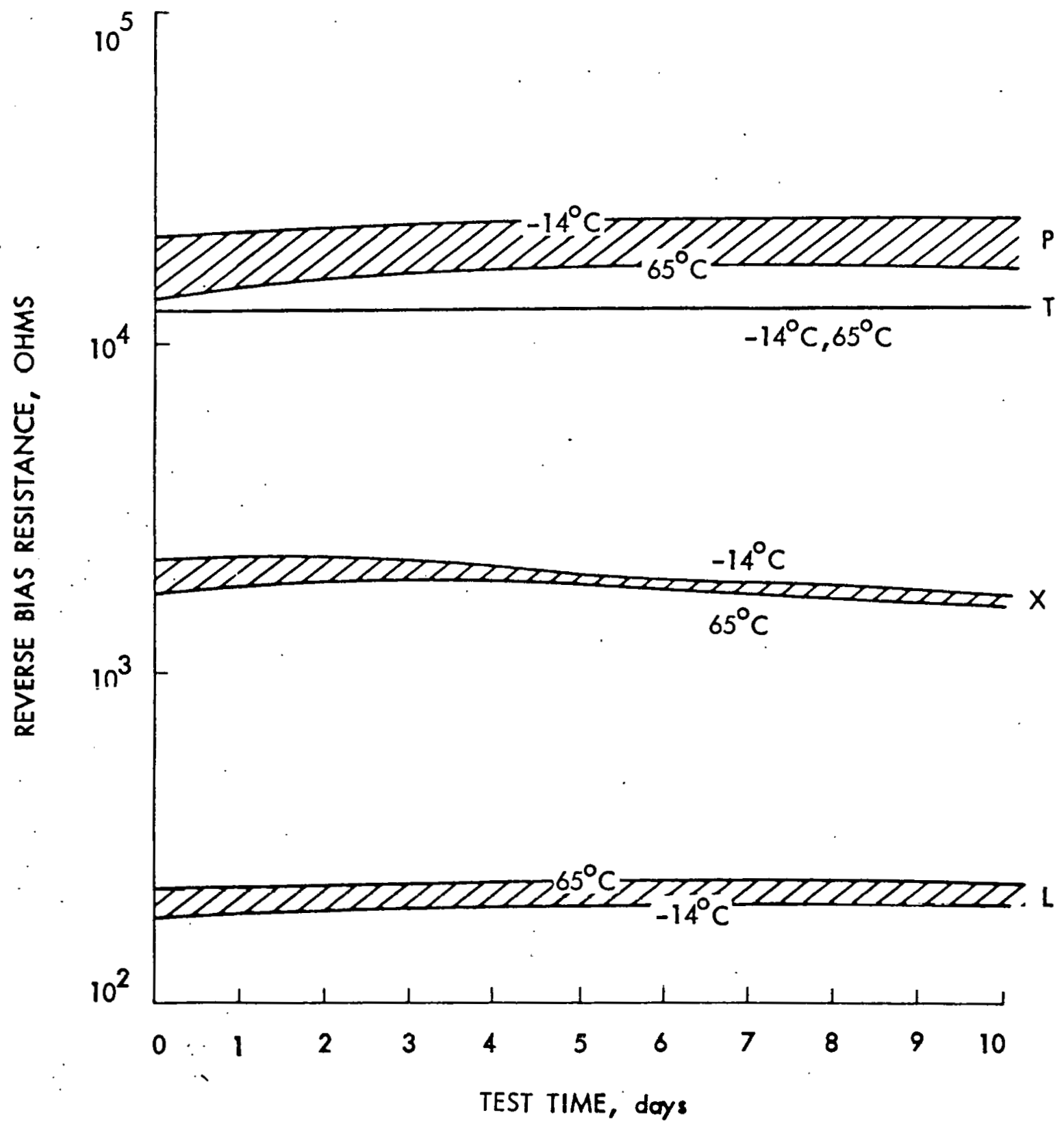

Figure 18. Mini-Mndule Reverse Bias Resistance, Phase 2 
modules' reverse bias resistances were not affected by temperature. Based on this data, the following guidelines are suggested for future tests in which reverse bias resistance is determined: the changes in resistance with time may be slight; modules from different manufacturers may have significant differences in reverse bias resistance which would necessitate different test equipment, e.g., different size power supplies; expect the temperature dependence of reverse bias resistance to vary greatly from manufacturer to manufacturer. 
The major corrosion mechanisms appear to be a tin migration effect on modules from manufacturer $P$ and a silver tarnishing or oxidation effect on modules from manufacturer L. The corrosion products may contain more complex oxides or other compounds, possibly with some moisture content. The discoloration of the silver metallization on $\mathrm{L}$ modules was the only observed change which may be related to the application of a bias voltage during the temperature-humidity test. However, due to the small sample size, additional tests would be required to confirm this possibility.

During Phase 2 testing, changes in appearance of other modules became much more evident after the second ten-day test. This may indicate the need for more extended temperature-humidity cycling than a single ten-day period. Incorporation of the freezing period for three hours during each 24-hour cycle would seem to be a realistic feature, considering the similarly wide temperature variations which may be encountered in field service.

Applying a forward or reverse bias to the cells during the test did not produce any observable effects. The currents used were only 5-20mA whereas the cells normally operate at currents of $500 \mathrm{~mA}$ to $2 \mathrm{~A}$. Additional bias-humidity tests could be planned at a considerably higher forward bias current. The bias voltage must be selected for each module type, however. Thus, this type of test is considerably more complicated to set up than simple unbiased temperature-humidity testing, or even testing with a bias voltage with respect to ground planes.

Because of the limited bias-related changes observed during this test development program a mandatory bias-humidity qualification test is not recommended at this time.

Comparison of module insulation resistance results suggests a moderate time dependency for some modules. Future tests should include test durations of sufficient length to account for this dependency.

Module reverse bias resistance results indicate a strong temperature dependence which varied widely between manufacturers.

The improved shadowing technique for measuring reverse bias voltage has proven to give good correlation with direct curve tracer measurements, and is thus a valuable technique when direct contact to the cells cannot be made. The effect of parallel paths needs to be taken into account, however, if these cannot be electrically isolated. 


\section{REFERENCES}

1. Hoffman, A., and Ross, R., "Environmental Qualification Testing of Terrestrial Solar Cell Modules," in Proceedings of 13th IEEE Photovoltaics Specialists Conference, June 5-8, 1978.

2. Griffith, J., Dumas, L., and Hoffman, A., "Environmental Testing of Flat Plate Solar Cell Modules," in Proceedings of the Solar Seminar on Testing Solar Energy Materials and Systems, May $22-24,1978$.

3. Military Standard, Test Methods, and Procedures for Microelectronics, MIL-STD-883B, August 31, 1977.

4. Thayer, S. B., "Reliability Methods in Japan," Journal of Environmental Sciences, Vol. XX, No. 1, January/February 1977, Pp. 30-31. 


\section{APPENDIX}

\section{REVERSE BIAS VOLTAGE MEASUREMENT BY THE SHADOWING TECHNIQUE}

\section{INTRODUCTION}

Ideally, the reverse bias voltage of a solar cell would be measured directly, utilizing a curve tracer, or a current source and high impedance voltmeter connected with separate leads directly to the cell. This latter arrangement, the "four point probe" configuration, is shown schematically in Figure $A-1$, together with the equivalent circuit for the cell. Typically $\mathrm{R}_{\mathrm{S}}$ is low and much less than $\mathrm{R}_{\mathrm{SH}}$, so the short circuit current of the cell, as measured directly, would be approximately equal to the internal short circuit current, $I_{S C}$ (Strictly speaking, this requires that the combination of the series resistance, the terminal contact resistance and lead resistance

: much lower than the parallel combination of $\mathrm{R}_{\mathrm{SH}}$ and the forward-biased diode resistance:) With the cell shadowed $\left(I_{S C} \approx 0\right)$, an equivalent shunt resistance may be measured at selected current values, $I_{0} \cdot$ Since $R_{S H}$ is typically a non-linear function of $I_{0}$, the current at which the measurement is made must be stated. Also, as indicated by the cell equivalent circuit in Figure A-1, such a measurement actually is the sum of the series and shunt resistance. Thus:

$$
\begin{aligned}
\text { Equivalent Shunt Resistance }=\frac{\mathrm{V}}{I_{0}} & =R_{S}+\frac{R_{S H} \mid}{I}=I_{0} \\
& \approx \frac{\left.R_{S H}\right|_{I}=I_{0}}{\left(\text { If: }: R_{S} \ll R_{S H}\right)}
\end{aligned}
$$

When dealing with a module, it may not be possible to make direct intact to the individual solar cells, either because the module must be 


\section{$5101-84$}

protected from any damage such as that caused by probing through the encapsuation, or because the package includes a glass cover plate or other structural features which make such contact difficult or impossible. In such cases, an indirect measurement of individual cell parameters must be made, based upon changes in illumination of one cell compared with the others, and electrical measurements at the module terminals. The shadowing technique to be described is one such measurement procedure.

The following discussion assumes that the module consists of a single series string of cells without bypass diodes. Series-parallel arrangements present additional difficulties of data interpretation and will not be discussed in the present treatment. The technique consists of illuminating all but one of the cells, while passing a known current (less than the illuminated short circuit current) through the module. As indicated in Figure A-2, this esults in reverse biasing the shadowed cell, while the remaining illuminated cells are in their normal forward biased condition.

The series string of $N$ cells may be treated as ( $N-1)$ illuminated cells in series with one shadowed cell. The module $I-V$ curve is therefore the summation of the illuminated I-V curve of (N-1) cells in series, and the reverse bias characteristics of the shadowed cell. This is shown in Figure A-3.

The I-V curve for the (N-1) illuminated cells cannot be directly measured, but may be approximated by assuming that all cells have similar open circuit voltages. Thus, the open circuit voltage of (N-I) cells is:

$$
\mathrm{v}_{\mathrm{OC}}=\mathrm{V}_{\mathrm{N}-1} \mathrm{C}_{\mathrm{N}} \cdot\left(\frac{\mathrm{N}-1}{\mathrm{~N}}\right)
$$


In the low current region, the $(\mathrm{N}-1)$ cell $\mathrm{I}-\mathrm{V}$ curve may be assumed to ave the same slope as the $\mathrm{N}-\operatorname{cel} 1 \mathrm{I}-\mathrm{V}$ curve, intersecting the $\mathrm{I}=0$ ordinate at $\mathrm{V}_{\mathrm{OC}}$. The validity of this assumption rests upon a consideration of the effect of shadowing a single cell. Refering to the equivalent circuit of the cell (Figure $A-1$ or $A-2$ ), shadowing cell " $\mathrm{X}$ " reduces $I_{S C}$ to near zero. The series resistance, $\mathrm{R}_{\mathrm{S}_{\mathrm{X}}}$, is unchanged and the shunt resistance, $\mathrm{R}_{S H_{X}}$, appears in series with the $\mathrm{R}_{S_{X}}$ and the remaining (N-1) cells. If $\mathrm{R}_{S H}$ were very low (nearly shorted cel1), such that the open circuit voltage of cell " $X$ " was much below average, then $\mathrm{V}_{\mathrm{OC}_{\mathrm{N}-1}}$ would remain nearly the same as $\mathrm{V}_{\mathrm{OC}}$. However, for a typical module, where $N \geq 20$, the error would be less than $5 \%$. A very high shunt resistance (compared with the average for the cells) would not affect the validity of the assumption. Similarly, since the series resistance s unaffected by shadowing, varlations from the average value would not affect $\mathrm{V}_{\mathrm{OC}}$ - The effect of series resistance of the shadowed cell is included in the slope of the $(\mathrm{N}-\mathrm{l}) \mathrm{I}-\mathrm{V}$ curve.

Referring to Figure A-3, the I-V curve when one cell is completely shadowed is similar to curve " $A$ ". The reverse bias voltage at the selected current, $I_{0}$, is, to a first approximation:

$$
\begin{aligned}
\mathrm{v}_{\mathrm{RB}} & \approx \mathrm{v}_{\mathrm{OC}},-\mathrm{v}_{\mathrm{N}-1} \\
& =\left(\frac{\mathrm{N}-1}{\mathrm{~N}}\right) \mathrm{v}_{\mathrm{OC}}-\mathrm{v}_{\mathrm{N}}
\end{aligned}
$$

The above expression assumes the $\mathrm{N}-\mathrm{cel1} \mathrm{I}-\mathrm{V}$ curve to have almost no hange in voltage with current in the region of interest (relatively low 
currents, well below the peak power point). While valld for modules having good fill factor, this assumption would not be as satisfactory for degraded modules. A better approximation is indicated in Figure A-4. Measuring the unshadowed module voltage, $V_{N}$, at the selected current, $I_{0}$, is easily accomplished, and the result may be substituted for $V_{O C_{N}}$ in equation (2).

$$
\frac{V_{R B}}{I}=I_{0}=\frac{V_{N} \mid}{I}=I_{0}\left(\frac{N-1}{N}\right)-\frac{V_{0} \mid}{I}=I_{0}
$$

An additional complication occurs because the individual cells often cannot be totally shielded. Reflected light from the underlying mounting surface or from side illumination impinges on the shadowed cell surface, generating a small "leakage" current which must be taken into account if an accurate result is to be obtained. This situation is indicated on the curves

I Figure A-4, where the shadowed cell generates a leakage current, $I_{P}$, actually its short circuit current under the small residual illumination. Experimentally, $I_{P}$ may be determined by locating point "P", the intersection of the shadowed $I-V$ curve, $A$, and the derived $(N-1) I-V$ curve. Once $I_{P}$ is known, $I_{0}$ (the selected current for reverse bias voltage measurement) is increased by the same amount when measuring the voltage. Thus, the reverse bias voltage of the selected cell at the chosen current, $I_{0}$, is:

$\frac{\mathrm{V}_{\mathrm{RB}}}{\mathrm{I}}=\mathrm{I}_{0}=\frac{\mathrm{V}_{0}}{\mathrm{I}}=\mathrm{I}_{0}+\mathrm{I}_{\mathrm{P}}-\left(\frac{\mathrm{N}-\mathrm{I}}{\mathrm{N}}\right) \stackrel{\mathrm{N}}{\mathrm{I}}=\mathrm{I}_{0}+\mathrm{I}_{\mathrm{P}}$ 
II. EXPERIMENTAL PROCEDURE

The following procedure assumes use of the circuit elements in Figure A-2, ad a source of 1llumination such as the JPL "Sun-u-1ator" which can illuminate all cells at a fairly repeatable intensity, even when cycled on and off.

Temperature of the module should be monitored, and maintained constant (preferably $28^{\circ} \mathrm{C} \pm 2^{\circ}$ ) since the module voltage typically drops by 0.1 volt per degree increase. This requirement necessitates operation of the Sun-u-lator for brief periods rather than continuously.

A. Determine and plot the low current portion of the fully illuminated I-V curve:

1. Adjust light intensity to give the desired short circuit current, current, $\mathrm{I}_{\mathrm{SC}_{\mathrm{N}}}$ (typically that corresponding to $100 \mathrm{~mW} / \mathrm{cm}^{2}$ intensity). $\mathrm{S}_{1}$ in position 1 . Maintain this intensity during all subsequent measurémènes.

2. Measure the open circuit voltage of the module, $\mathrm{v}_{\mathrm{OC}_{\mathrm{N}}}$. $\mathrm{S}_{1}$ in position 2.

3. Measure the module voltage and current with a resistive load which results in a current in the range of $100-200 \mathrm{~mA} . \mathrm{s}_{1}$ in position 3.

4. Plot the two points from steps 2 and 3 , above, on an expanded scale, as shown in Figure A-5. The straight line through them approximates the low current portion of the I-V curve.

5. Calculate and plot: $\mathrm{V}_{\mathrm{OC}}=\left(\frac{\mathrm{N}-1}{\mathrm{~N}-1}\right){ }_{\mathrm{OC}_{\mathrm{N}}} \cdot$ Draw a line through this point, parallel to the line previously drawn. 
Set up $R_{3}$ for positive regulation of the constant current power supply, as follows:

1. Set the constant current supply to a value equal to the selected current at which the reverse bias voltages are to be measured, $I_{0}$.

2. Adjust $R_{3}$ so that the voltage across the constant current supply is a sma11, positive value (polarity as indicated in Figure A-2), with $I_{0}$ flowing through the module, $R_{3}$ and the constant current supply. $\mathrm{S}_{1}$ in position 5.

Note: This adjustment is necessary because most constant current supplies will only regulate current with a positive output voltage. With $R_{3}$ too small, the illuminated module would force more than the desired current, $I_{0}$, through the supply resulting in a negative supply polarity and loss of regulation.

C. Perform the reverse bias voltage measurement on each cell of interest as follows:

1. Deterinine the leakage current level, $I_{P}:\left(S_{1}\right.$ in position 4.$)$

a) Position the shadow mask over the cell of interest.

b) Adjust $\mathrm{R}_{2}$ while observing the module voltage and current, so that these values, $V_{P}$ and $I_{P}$, fall on the $(N-1) I-V$ curve plotted previously (Figure A-5, step A-5, above). Record these values of $V_{P}$ and $I_{P}$. 


\section{$5101-84$}

2. Set the constant current supply to the value $I=I_{0}+I_{p}$, where $I_{0}$ is the selected current for measuring the reverse bias voltage (typica11y $100 \mathrm{~mA}$ or $250 \mathrm{~mA}$ ).

3. Without moving the shadow mask, measure the module voltage, $\mathrm{V}_{0}$, at this current level, $\mathrm{I}_{0}+\mathrm{I}_{\mathrm{P}} \cdot \mathrm{(S}_{1}$ in position 5.)

4. Calculate the reverse bias voltage and equivalent shunt resistance at $I_{0}$ :

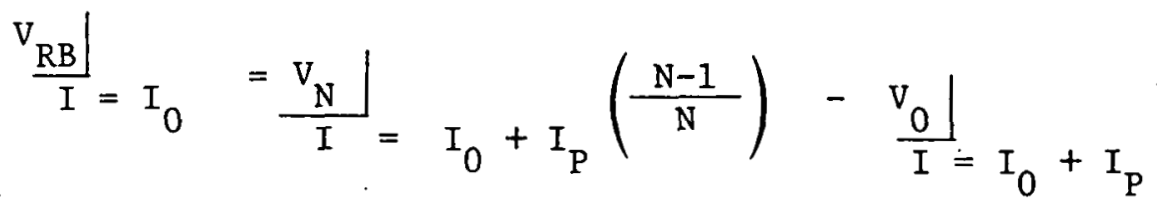

where $\frac{V_{N}}{I}=I_{0}+I_{P} \quad$ is obtained from the plotted $I-V$ curve of

Figure A-5. (Note: If the fully illuminated $I-V$ curve has very little slope, and $\mathrm{V}_{\mathrm{RB}}$ is appreciable, $\mathrm{V}_{\mathrm{OC}_{\mathrm{N}}}$ may be substituted for $\frac{\left.V_{N}\right\rfloor}{I=I_{0}+I_{P}} \quad$ with little error.)

Equivalent shunt resistance: $E S R=\frac{V_{R B}}{I_{0}}$ 


\section{SINGLE CELL EQUIVALENT CIRCUIT}

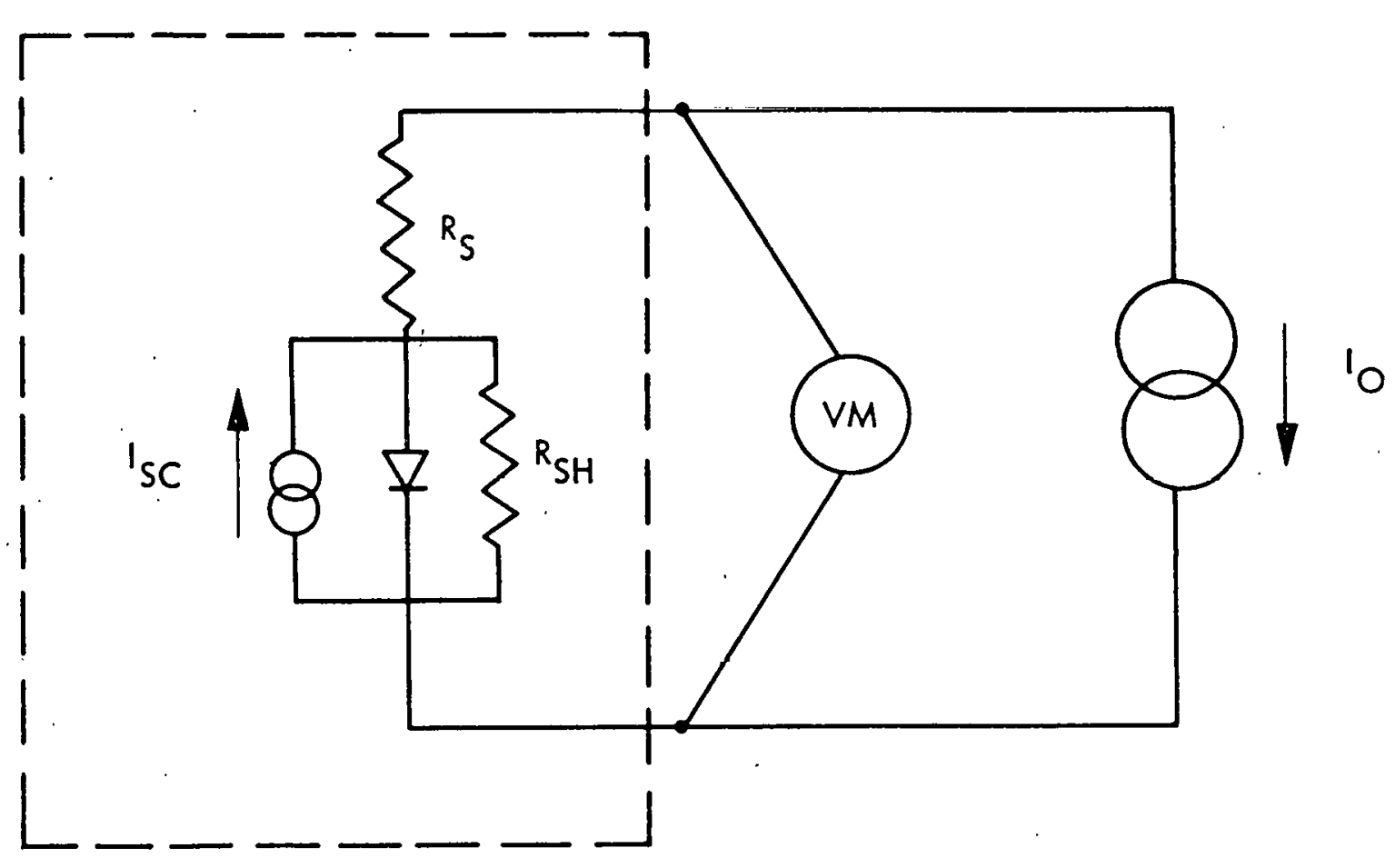

Figure A-1 Four-Point Probe Configuration for Measurement of Solar Cell Parameters 


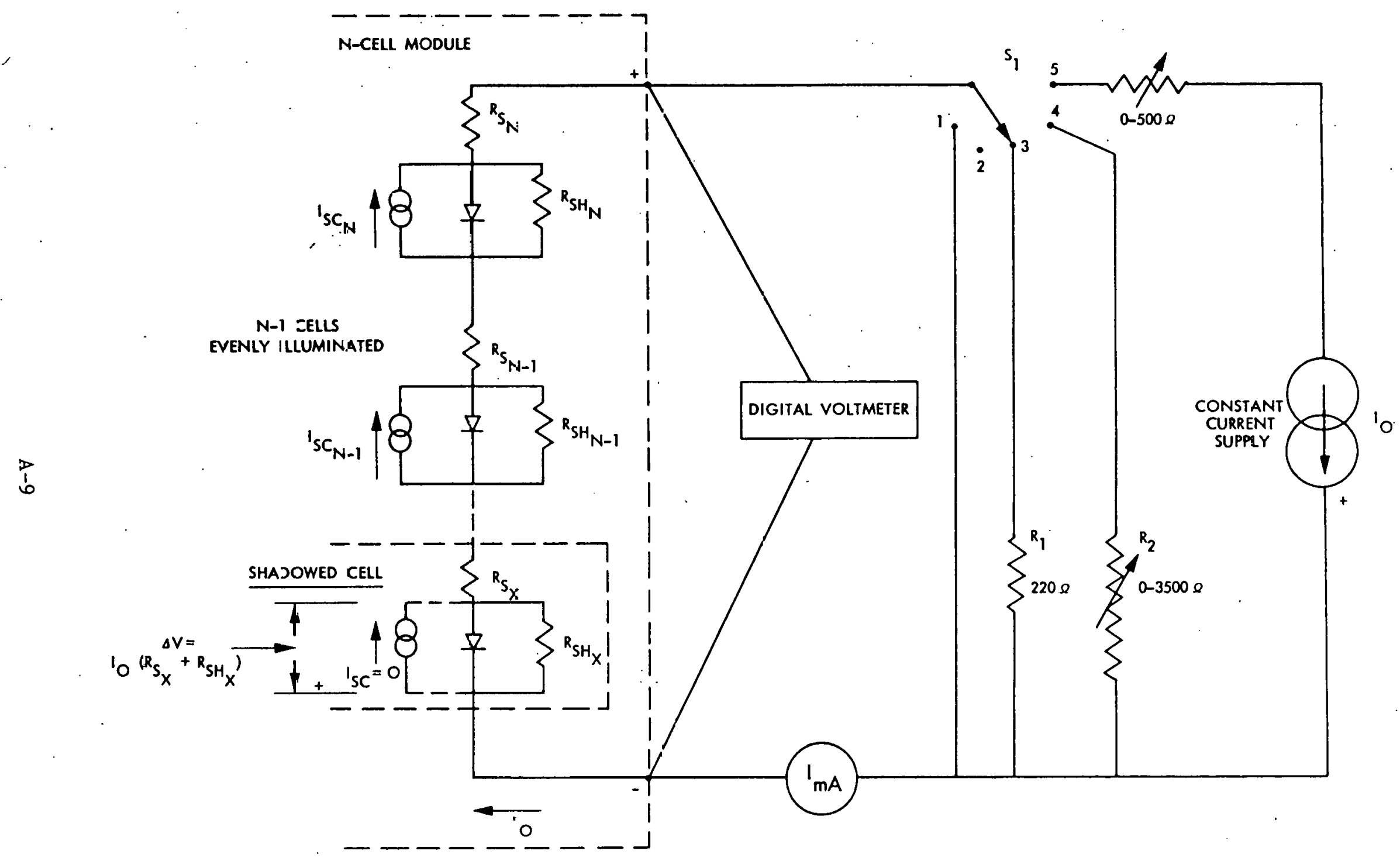

Figure A-2. Schematic Diagram of Shadow Measurement Circuitry and Instrumentation 


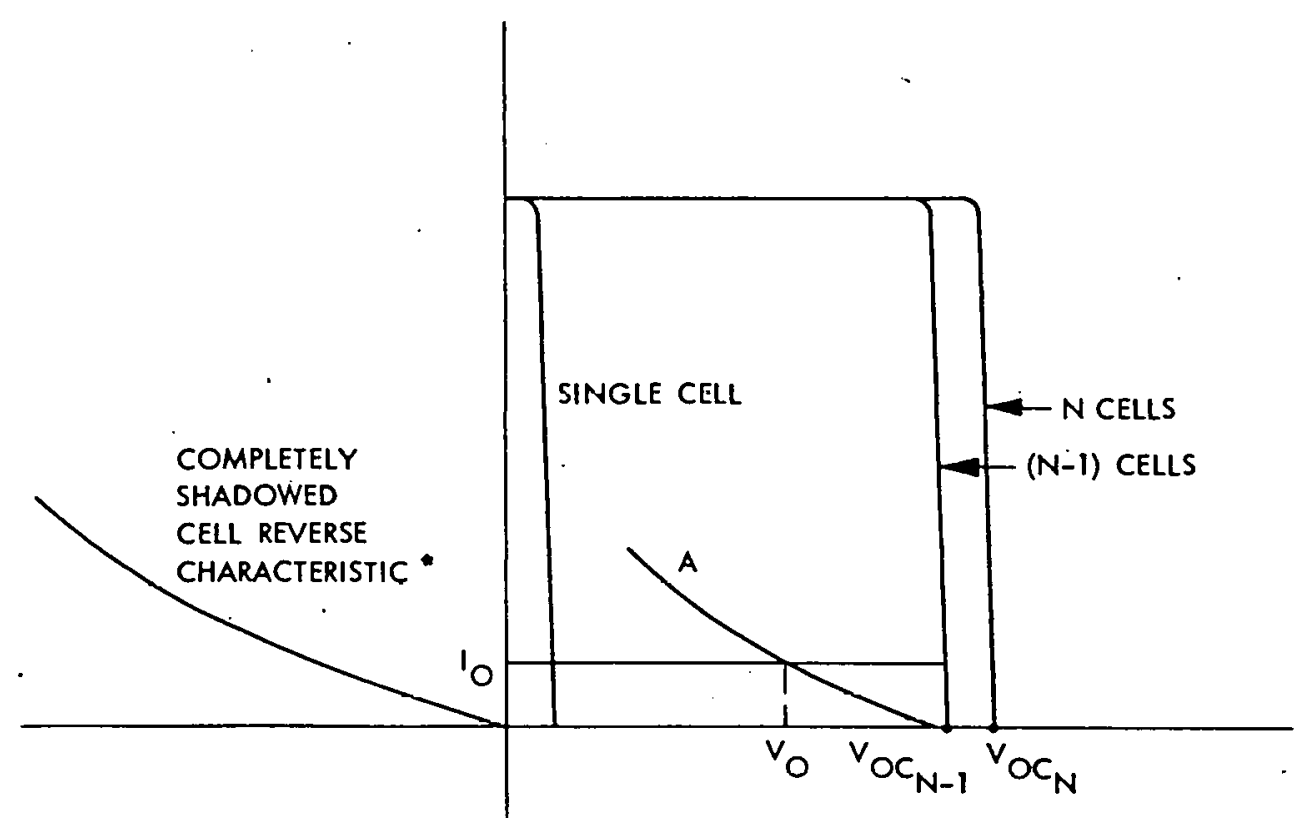

$A=$ SUMMATION OF (N-1) CURVE AND SHADOWED SINGLE. CELL REVERSE CHARACTERISTIC.

* shadowed Cell reverse characteristic less series resistance. THE SERIES RESISTANCE EFFECT OF THE SHADOWED CELL APPEARS IN THE (N-I) I-V CURVE.

Figure A-3. Composite I-V Curve of One Completely Shadowed Cell in Series with $(\mathrm{N}-1)$ Illuminated Cells

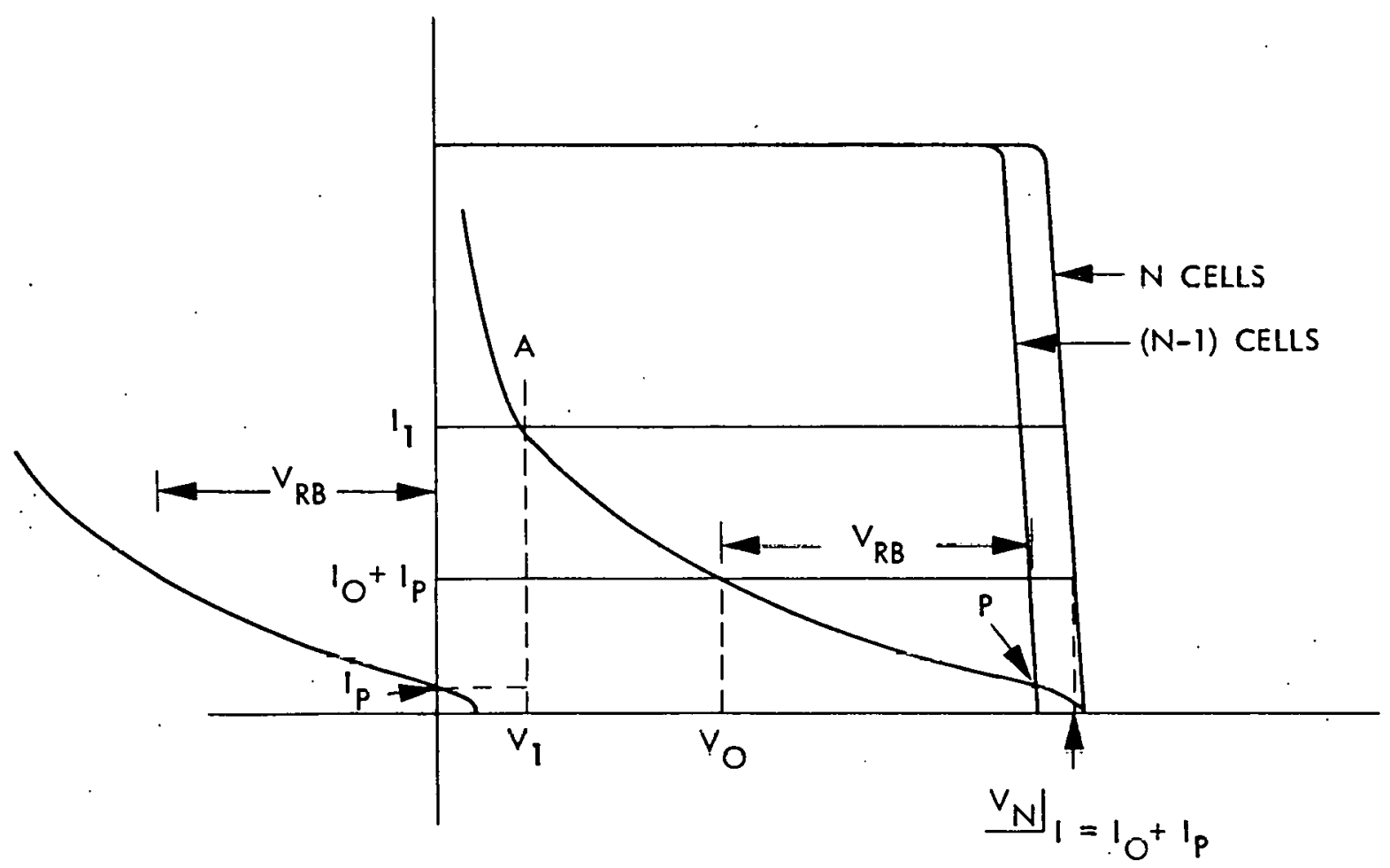

Figure A-4. Composite I-V Curve of One Partially Shadowed Cell in Series with $(\mathrm{N}-1)$ Illuminated Cells 
$5101-84$

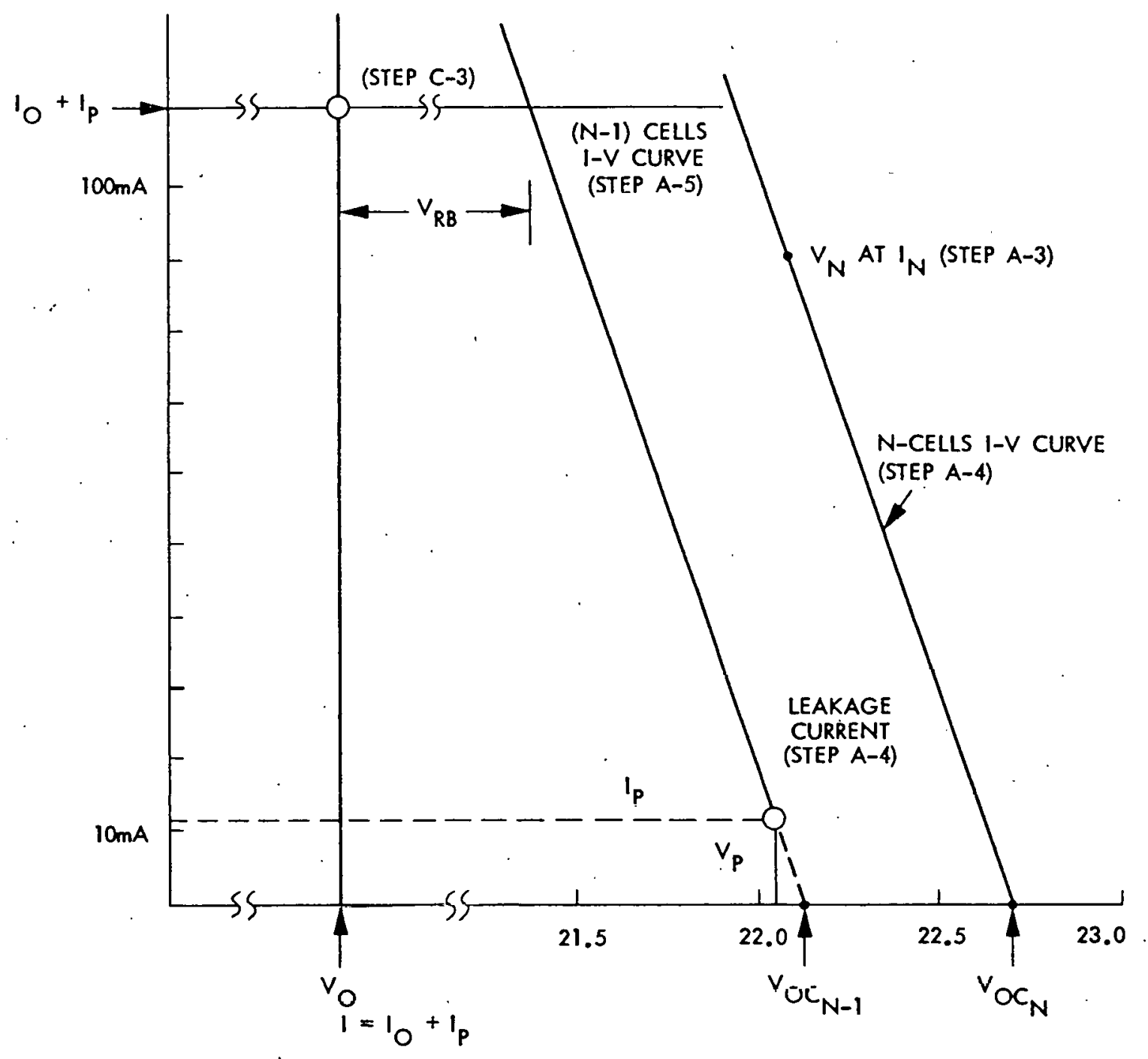

Figure A-5. Typical Expanded Scale I-V Plot for Reverse Bias Voltage Determination 